\title{
Electrochemical Dehalogenation of Organic Pollutants
}

\author{
Dennis G. Peters, ${ }^{*}$ Caitlyn M. McGuire, Erick M. Pasciak, Angela A. Peverly, Lauren M. Strawsine, \\ Elizabeth R. Wagoner, and J. Tyler Barnes
}

Department of Chemistry, Indiana University, Bloomington, IN 47405, USA. Tel.: +1 8128559671 peters@indiana.edu

Received January 17 $7^{\text {th }}, 2014 ;$ Accepted March $3^{\text {rd }}, 2014$.

\begin{abstract}
This review summarizes our own research, published since 2004, dealing with electrochemical reduction of halogenated organic compounds that are environmental pollutants. Included are sections surveying the direct and mediated reduction of the following species: (a) chlorofluorocarbons; (b) pesticides, fungicides, and bactericides; (c) flame retardants; and (d) disinfection by-products arising from the chlorination of water. To provide the reader with a perspective of these topics beyond our own work, a total of 238 literature citations, pertaining to studies conducted in numerous laboratories around the world, appears at the end of this review.

Keywords: Chlorofluorocarbons (CFCs); Flame retardants; Disinfection by-products (DBPs); Pesticides; Direct reduction; Catalytic reduction.
\end{abstract}

\section{Introduction}

Over the past 40 years, our laboratory has been involved in a variety of studies of the electrochemical reduction of halogenated organic compounds. During the most recent decade, however, we have become interested especially in the electrochemistry of halogenated environmental pollutants, as an avenue to the discovery and development of procedures for the determination and remediation of these substances.

This review is intended to serve several purposes. First, it is meant to provide a summary of all of our research pertaining to the direct and mediated electrochemical reduction (remediation) of several classes of halogenated organic pollutants, including chlorofluorocarbons (CFCs), pesticides, flame retardants, and disinfection by-products that arise as a consequence of the chlorination of water for human use. Second, we have added a final section devoted to new directions that environmental electrochemistry might take. Third, to put our work into a broader context, we have endeavored to provide a thorough survey of the literature dealing with the electrochemical behavior of these various categories of pollutants so that the interested reader can become aware both of what has been accomplished globally so far and of what opportunities and challenges remain open for future exploration and development. Finally, because this review is necessarily limited in the details that can be presented, the extensive set of references compiled at the end should be a valuable starting point for electrochemists seeking to contribute to the field of environmental electrochemistry; these specific references, as well as their own bibliographies, should be consulted as primary and detailed sources of information about many aspects of this interesting and rapidly expanding field.
Resumen. Esta revisión resume nuestras investigaciones publicadas desde el 2004, que centran en la reducción electroquímica de compuestos orgánicos halogenados que son conocidos como contaminantes del medio ambiente. Se incluyen secciones que examinan las reducciones directas y mediadas de las siguientes especies: (a) clorofluorocarbonos; (b) pesticidas, fungicidas, y bactericidas; (c) retardantes de llama; y (d) subproductos de la desinfección de la cloración del agua. Para proveer al lector una perspectiva completa incluyendo estos temas más allá de nuestro trabajo, un total de 238 citas bibliográficas, perteneciendo a los estudios realizados en numerosos laboratorios de todo el mundo, son incluidos al final de esta revisión.

Palabras clave: Clorofluorocarbonos (CFCs); Retardantes de llama; Subproductos de la desinfección; Pesticidas; Reducción directa; Reducción catalítica.

As an aid to the reader, the list of references is preceded by a compilation of common abbreviations for various compounds, solvents, and supporting electrolytes employed throughout this review.

\section{Chlorofluorocarbons (CFCs)}

In 1974, Rowland and Molina [1] postulated that chlorofluorocarbons (CFCs) could deplete the stratospheric ozone layer. Subsequent research confirmed that one chlorine atom cleaved from a CFC molecule might degrade 100,000 molecules of ozone [2]. Thus, the Montreal Protocol on Substances that Deplete the Ozone Layer was introduced in 1986, initiating global cessation of production and use of CFCs [3]. A consequence of this action was the accumulation of CFC stockpiles to an amount of 2.25 megatons in 2009; although these CFCs are no longer used, they remain an atmospheric threat [4]. Electrochemical degradation of banked CFCs has been thoroughly studied, because, in comparison with traditional techniques such as high-temperature incineration, this approach involves milder reaction conditions, less energy, lower operating costs, improved product selectivity, and avoidance of secondary pollutants such as carbon dioxide and hydrogen halides. Many examples in which CFCs are electrochemically converted to hydrofluorocarbons (HFCs) and fluorocarbons (FCs) have been reported; these fluorinated compounds are harmless to stratospheric ozone and serve as valuable materials for the synthesis of polymers and biologically active substances as well as replacement compounds for the refrigerant and propellant industries [5]. Shown in Figure 1 are structural formulas and shorthand designations for the various CFCs and their 


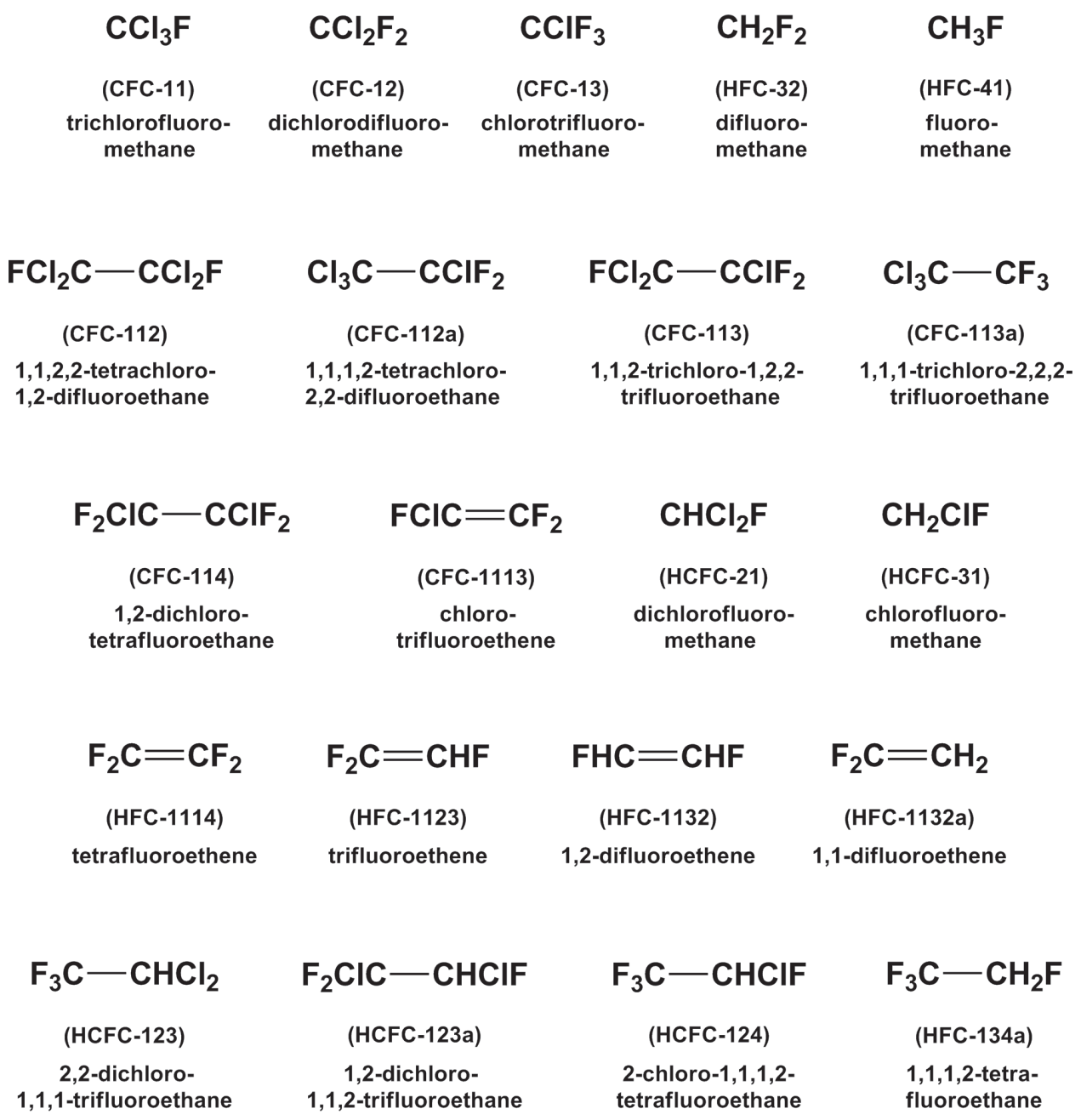

Fig 1. Structures, shorthand designations, and names for various CFCs and their reduction (degradation) products.

reduction (degradation) products mentioned in the following paragraphs.

\section{A. Direct Electrochemical Reduction of CFCs}

In an early patent by Montecatini Edison [6], a mercury cathode was utilized for reduction of CFC-114 and CFC-113 in an ethanol-water mixture containing potassium acetate to afford mainly HFC-1114 and CFC-1113, respectively; the same study also revealed that electrodegradation of CFC-11 and CFC-12 under the same conditions produces HFC-41 and HFC-32, respectively, in moderate to low yields. In subsequent work, Smirnov and co-workers [7] used different solvents and cathode materials to examine the reductions of CFC-114 and CFC-113; this study demonstrated that CFC-113 can be electrochemically converted to a mixture of CFC-1113 (78\%) and HFC-1123 (10\%). For the reduction of CFC-113 at a zinc-coated copper cathode in aqueous media, less efficient dechlorination was reported by Wawzonek and Willging [8].

Tezuka and Iwasaki [9] explored the electrochemical reductions of CFC-112, CFC-112a, CFC-113, and CFC-113a at mercury, platinum, and carbon cathodes in a hexameth- ylphosphoramide-water mixture containing $\mathrm{TBABF}_{4}$. Electrolysis of CFC-112, CFC-112a, and CFC-113 resulted primarily in formation of the olefin arising by the loss of two chlorines; when CFC-113a was reduced at mercury, the major product was HCFC-123, whereas significant yields of the olefin derivative were produced at platinum and carbon cathodes.

Savall and co-workers $[10,11]$ sought to dechlorinate CFC113 via electrochemical reduction at a rotating zinc electrode in water-methanol mixtures containing ammonium chloride. A more extensive set of investigations of the electrodegradation of CFC-113, as well as of CFC-11, was carried out by Cabot et al. [12-16]; these studies employed a palladium-based hydrogen diffusion anode so that a one-compartment cell could be used at lower energy costs. At lead or copper cathodes in aqueous methanol, CFC-113 was converted to mixtures of HCFC-123a, CFC-1113, HFC-1132a, HFC-1132, HFC-1123, HFC-41, and difluoroethane [12-14]. Under similar conditions, reduction of CFC-11 led predominantly to HCFC-21, along with small amounts of HCFC-31, HFC-41, and methane $[14,16]$.

Another novel electrode system, namely hydrophobized cathodes comprised of acetylene black containing polytetra- 
fluoroethylene ( $40 \%$ by weight), was employed by Kornienko et al. [17] and by Kolyagin et al. [18] to enhance the conversion of CFC-113 to CFC-1113 in aqueous $3.0 \mathrm{M}$ lithium chloride solutions. Inaba and co-workers [19] introduced an innovative cell design to accommodate volatile CFCs more efficiently, and they employed a metal-plated solid polymer electrolyte composite cathode for the reduction of HCFC-124 in aqueous sodium hydroxide to form only HFC-134a at a rate that increased when the solution was irradiated with a xenon arc lamp.

Gas-diffusion electrodes were utilized by Sonoyama and co-workers [20-23] for the electrochemical reduction of CFC12 and CFC-13. Twelve different metal electrodes (Ni, Pt, Zn, $\mathrm{Ag}, \mathrm{Cu}, \mathrm{Ru}, \mathrm{Pd}, \mathrm{Pb}, \mathrm{Co}, \mathrm{Cr}, \mathrm{Sn}$, and $\mathrm{In}$ ) were employed to study the reduction of $\mathrm{CFC}-12$ in an aqueous sodium hydroxide medium; it was discovered that hydrogen gas evolution could be minimized and that faradaic efficiency for production of HFC-32 could be maximized when a lead cathode was used [20]. Under similar conditions, metal-phthalocyanine supported gas-diffusion electrodes demonstrated a strong bias toward the formation of completely dehalogenated products (ethane, methane, and ethene) via reduction of CFC-12 [21]. A change in the solvent-supporting electrolyte to a more aprotic system and an increase in the applied pressure revealed that CFC-12 can be electrochemically reduced to favor the production of HFC-1123 [22]. Finally, the reduction of CFC-13 at a silver electrode was explored in a $\mathrm{CH}_{3} \mathrm{CN}-\mathrm{TBABr}$ medium in the presence and absence of carbon dioxide (a carbanion trap); in a carbon dioxide-containing system, the current efficiency for the formation of trifluoroacetic acid was as high as $85 \%$ [23].

Work conducted in the laboratory of Kyriacou [24-27] focused on the catalytic effects of various cathode materials $(\mathrm{Ag}, \mathrm{Au}, \mathrm{Cu}, \mathrm{Pt}$, and $\mathrm{Ni})$ for the reduction of $\mathrm{CFC}-12$ in $\mathrm{CH}_{3} \mathrm{CN}-\mathrm{TBABr}$; silver was found to promote the highest rate of formation of degradation products [24]. In addition, effort was directed to assess how the choice of organic solvent affects the product selectivity [25], how the use of a silver-deposited Nafion ${ }^{\circledR}$ solid-polymer electrode can enhance the efficiency of the formation of HFC-32 via reduction of CFC-12 [26], and how, in an aqueous medium, the rate of formation of reduction products depends on $\mathrm{pH}$ [27].

Titov et al. [28-30] and Doherty et al. [31] have reported findings that pertain to the effects of the reaction medium and cathode material on the reduction of CFC-113. Various lowand room-temperature ionic liquids were investigated and compared to the electrochemical behavior of CFC-113 observed in a conventional $\mathrm{DMF}-\mathrm{TBABF}_{4}$ medium; the higher viscosity and lower conductivity of an ionic liquid cause cathodic peak potentials to be more negative and peak currents to be smaller. Moreover, cyclic voltammetric peak potentials for reduction of CFC-113 become more positive as the cathode material is changed from glassy carbon to platinum to silver (although platinum exhibits slow electron-transfer kinetics); therefore, a silver cathode was judged to best facilitate dehalogenation of CFC-113 to afford CFC-1113, owing to the proposed formation of an activated complex involving an adsorbed CFC-113 molecule and a silver atom on the electrode surface.
Direct reduction of CFC-113 at silver and glassy carbon electrodes in three solvents (propylene carbonate, $\mathrm{CH}_{3} \mathrm{CN}$, and DMF), each containing $\mathrm{TMABF}_{4}$, was recently explored in our laboratory [32]. As discovered in earlier research, a silver cathode demonstrated catalytic ability to cleave carbon-halogen bonds reductively, which manifested itself in a shift in reduction potentials to more positive values relative to those for a glassy carbon cathode. Two irreversible cathodic peaks were seen for the cyclic voltammetric reduction of CFC-113 at silver in each of the three solvents, and controlled-potential (bulk) electrolysis confirmed that direct reduction of CFC-113 at silver proceeds in a manner similar to that at a carbon cathode, although the potential needed to reduce all carbon-chlorine bonds is significantly more positive when a silver cathode is employed. Finally, when a 50:50 mixture of water and organic solvent $\left(\mathrm{CH}_{3} \mathrm{CN}\right.$ or DMF) is used, it is more difficult to cleave the last carbon-chlorine bond of CFC-113, leaving HFC-1123 as a minor (but significant) product and giving CFC-1113 as the major product.

\section{B. Catalytic Reduction of CFCs with Electrogenerated Mediators}

In addition to investigations focused on an enhancement of the direct electrodegradation of CFCs by choice of cathode material, numerous studies have been performed to promote CFC reduction with the aid of a homogeneous-phase electrontransfer mediator. In our laboratory, both nickel(I) salen and cobalt(I) salen have been electrogenerated at a carbon cathode and used in situ to reduce CFC-113 in DMF-TBABF 4 [33,34]. When a $1.0 \mathrm{mM}$ solution of the catalyst precursor (nickel(II) salen or cobalt(II) salen) is used, we observed that, at low concentrations $(\leq 10 \mathrm{mM})$ of CFC-113, the principal reduction product is HFC-1123, along with some HFC-134a. With the same environment, but with higher concentrations $(\geq 10 \mathrm{mM})$ of CFC-113, complete dechlorination does not take place and the major product is CFC-1113 along with unreduced CFC113 , a result attributable to the fact that the active catalyst can no longer be regenerated, which effectively discontinues the catalytic cycle with CFC-113 at the applied potential. Interestingly, when the direct reduction of CFC-113 was conducted at a carbon electrode, two cathodic peaks were observed in a cyclic voltammetry experiment; and, it was confirmed, with the aid of controlled-potential electrolysis, that the first stage of reduction of CFC-113 corresponds to cleavage of two carbon-chlorine bonds to form CFC-1113 and that the second stage of reduction involves cleavage of the last carbon-chlorine bond to afford HFC-1123 [33]. In an investigation [35] of the catalytic reduction of CFC-113a by cobalt(I) salen electrogenerated at a carbon cathode in DMF-TMABF 4 , solutions initially containing $2.0 \mathrm{mM}$ cobalt(II) salen in the presence of 10 to $30 \mathrm{mM}$ CFC-113a proved inadequate to achieve complete dechlorination of the CFC; a substantial quantity (up to $51 \%$ ) of unreduced CFC-113a was found and the products were mono- or dichlorinated species.

Using several different nickel(I) species (with azamacrocyclic and bipyridine ligands) that were electrogenerated at a 
platinum cathode, Titov et al. [36] demonstrated that the catalytic degradation of CFC-113 in DMF-TBABF 4 is a feasible undertaking; the proposed reaction scheme involves interaction of the substrate with a nickel(I) complex to form a nickel(III)organohalogen intermediate that immediately undergoes reduction to afford CFC-1113 in an overall two-electron process, after which CFC-1113 is converted to HFC-1123 in almost $100 \%$ yield. Titov and co-workers [37] examined the reduction of geminal and vicinal CFCs at glassy carbon and silver cathodes in the presence of $\mathrm{SO}_{2}$ and $\mathrm{CO}_{2}$. In the case of geminal CFCs, such as CFC-113a, $\mathrm{SO}_{2}$ acts both as a reagent and an electron-transfer mediator to form $\mathrm{CF}_{3} \mathrm{CCl}_{2} \mathrm{SO}_{2}^{-}$and HCFC123 at a potential $1.3 \mathrm{~V}$ more positive than in the absence of $\mathrm{SO}_{2}$. In contrast, $\mathrm{SO}_{2}$ serves only to catalyze the reduction of vicinal CFCs (such as CFC-113) to form fluorinated ethenes. Similar reactions are observed when the geminal species CFC$113 \mathrm{a}$ is reduced in the presence of $\mathrm{CO}_{2}$; the highest yield of fluorine-containing carboxylic acids is achieved when a silver cathode is employed.

Studies performed by Koshechko and Pokehodenko [38] expanded on the work of Titov et al. and focused on the electrochemical remediation of CFC-113 and CFC-12 at platinum electrodes with several classes of electron-transfer mediators. Their findings confirmed the results pertaining to the catalytic effects of nickel(I) complexes and $\mathrm{SO}_{2}$, and also revealed that aromatic outer-sphere electron-transfer mediators, such as $E$-azobenzene, can efficiently convert CFC-113 to HFC-1123 in $85 \%$ yield at significantly more positive potentials.

Work conducted in our laboratory involved the catalytic degradation of CFC-113 in the presence of electrogenerated cobalt(I) salen [39] in a DMF-TBABF 4 medium saturated with $\mathrm{CO}_{2}$; recently, we have finished an unpublished study pertaining to the use of electrogenerated nickel(I) salen in DMF-TBABF 4 saturated with $\mathrm{CO}_{2}$. Like the results found by Titov et al. [37], negligible amounts of carboxylic acids were detected upon reduction of this vicinal CFC, but higher yields of more dechlorinated products (HFC-1132 and HFC-1132a) were obtained; these observations suggest the possibility that $\mathrm{CO}_{2}$ mediates electron transfer to cause more effective cleavage of carbon-chlorine bonds. Direct reduction of CFC-113 in the presence of $\mathrm{CO}_{2}$ at a glassy carbon cathode gives rise to a single cathodic peak, as opposed to the two peaks recorded for direct reduction of CFC-113 in the absence of $\mathrm{CO}_{2}$. However, no significant changes in the distribution of products were observed despite the difference in cyclic voltammetric behavior.

\section{Pesticides, Fungicides, and Bactericides}

Pesticides were first developed at the dawn of agricultural society when human survival depended on the protection of vital food sources. Pesticides are still widely used to promote human health and crop production; however, research into the negative effects of these substances has forced care in their application. According to the United States Environmental Protection Agency, a pesticide is defined as "any substance or mixture of substances intended for preventing, destroying, repelling, or mitigating any pest," including insecticides, fungicides, and herbicides [40]. These species are often categorized by their chemical functional groups, in the order in which they were first historically applied as pesticides, and by the mechanism in which they disrupt the target pest. This section of our review begins with a brief mention of the electrochemical study of organophosphate pesticides, first developed to disrupt the production of the neurotransmitter acetylcholine. Similarly, dicarboximides were developed to inhibit triglyceride synthesis, and studies of their electrochemical behavior will be discussed. A greater part of this section focuses on organohalogen compounds, notable for their toxicity and persistence in the environment. Then the electrochemical behavior of newly developed contentious triazines and benzonitriles will be presented. Finally, pyrethroids are discussed, as the newest generation of pesticides designed to mimic natural insect hormones.

\section{A. Organophosphates}

Organophosphates, some of which are chlorinated, were among the first chemical pesticides to be developed due to their neuroactivity. These compounds have become significant pollutants owing to their overuse in agriculture and as chemical warfare agents; consequently, monitoring of these species in the environment is especially important for human health and security. Studies of the electrochemical behavior of some of these pesticides, including a few chlorinated species, have been reported $[41,42]$. Organophosphates possessing a $\mathrm{C}=\mathrm{C}$ motif (such as dichlorvos, dicrotophos, chlorfenvinphos, and crotoxyphos) can be reduced at a mercury cathode; however the phosphate group usually remains intact in the product, indicating that further work could be done to determine whether electrochemistry will provide an efficient means of remediation for this class of pollutants.

\section{B. Dicarboximide Pesticides}

Significant research has been conducted to investigate the electrochemical degradation of dicarboximides. This family of fungicides is globally produced as inhibitors of triglyceride biosynthesis; unfortunately, despite the effectiveness of dicarboximides against a large palette of fungi, recent studies have established that these compounds serve as endocrine disruptors and have been shown to have antiandrogenic and reproductive developmental effects [43]. Dicarboximides have a common structural feature, which is a 3,5-dichlorophenylimide moiety bound to a substituted five-membered heterocycle [44].

Early work by Will [45] provided a brief discussion of the electrochemical reduction of vinclozoline. Pospíšil and coworkers [46] examined the electrochemical behavior of vinclozoline (1), iprodione (2), and procymidone (3) in $\mathrm{CH}_{3} \mathrm{CN}-$ $\mathrm{TBAPF}_{6}$ at a mercury cathode, and they observed two stages of reduction.

Bulk electrolysis of these compounds at a potential corresponding to the first stage of reduction revealed that the main degradation pathway involves elimination of the hetero-ring and cleavage of one or both carbon-chlorine bonds; in the case of 1 , products arising from reduction of the $\mathrm{O}-\mathrm{C}=\mathrm{O}$ moiety 


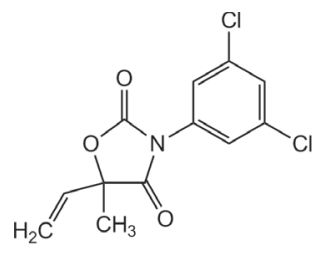

1<smiles>CC(C)NC(=O)N1CC(=O)N(c2cc(Cl)cc(Cl)c2)C1=O</smiles>

2

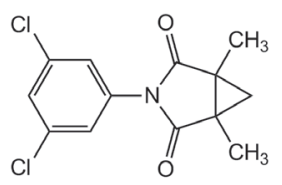

3

Fig. 2. Structures of dicarboximide pesticides: vinclozoline (1), iprodione (2), and procymidone (3).

of the heterocyclic ring were detected [46]. In a subsequent study [47], it was found that formation of host-guest complexes of cyclodextrin with each of the three dicarboximides (1-3) in $\mathrm{DMSO}_{-} \mathrm{TBAPF}_{6}$ leads to preferential reduction of the two carbon-chlorine bonds at a mercury electrode. Sreedhar and colleagues $[48,49]$ examined the reduction of $\mathbf{1}$ at mercury and platinum electrodes in buffered electrolyte solutions over a $\mathrm{pH}$ range of 2.0-12.0 to further elucidate a mechanism. A polarographic investigation of $\mathbf{3}$ in Britton-Robinson buffer ( $\mathrm{pH}$ 2.0-6.0) with DMF as solvent was carried out by Sreedhar et al. [50], who concluded that a four-electron reduction of the two carbonyl groups occurs.

\section{Halogenated Organic Pesticides}

A recent focus of research in our laboratory has been the electrochemical reduction of halogenated organic pesticides. These compounds are notoriously toxic, due to their propensity to bioaccumulate throughout the environment. Furthermore, the electroreduction of carbon-halogen bonds is a well established field, allowing the bulk electrolysis of these persistent pollutants and the development of selective electrochemical techniques to convert these substances into innocuous and, in some cases, profitable compounds.

DDT and its degradation products. In all likelihood, the most well known pesticide in this class is 4,4'-(2,2,2-trichloroethane-1,1-diyl)bis(chlorobenzene), commonly referred to as DDT. Though highly utilized in the agricultural sector and as a malaria vector control, it has been banned from use in most industrialized nations due to evidence associating it with cancer and with reproductive and neurophysiological disorders. Electrochemical reduction of DDT was first studied in 1953 at a dropping mercury electrode in DMF, and the major product was determined to be DDD [51]. Shown in Figure 3 are the structures of DDT and its degradation products. Subsequent investigations involved the reduction of DDT in a variety of solvent systems and at a variety of electrodes (including mercury, lead, nickel, and graphite felt) [52-56]; this work demonstrated that, depending on the choice of experimental conditions, different degrees of dechlorination could be achieved to produce DDD, DDE, DDMU, and DDNU [52-56]. In addition, ionic liquids have been employed as media for the electrochemical degradation of DDT [57].

Our own research began with a study of the reduction of DDT at a glassy carbon electrode in DMF-TMABF 4 [58]. Evidence gleaned from cyclic voltammetry and bulk electrolysis suggested a mechanism in which DDT is reduced sequentially, first to DDD and then to DDMS; because these two processes dominate a bulk electrolysis, it was found that reduction of DDT is essentially a four-electron process. Cyclic voltammograms for the reduction of DDD mimic those of DDT, except

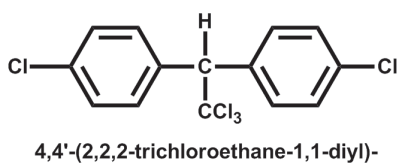
bis(chlorobenzene) (DDT)
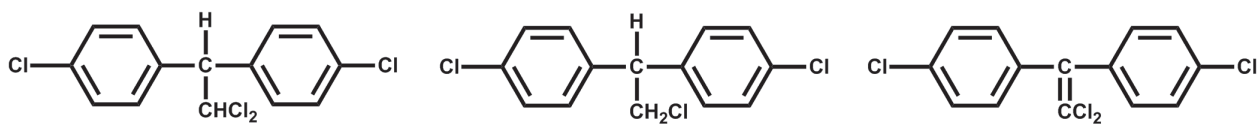

4,4'-(2,2-dichloroethane-1,1-diyl)bis(chlorobenzene) (DDD)

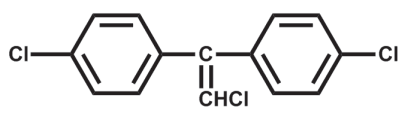

4,4'-(2-chloroethane-1,1-diyl)bis(chlorobenzene) (DDMS)

4,4'-(2,2-dichloroethene-1,1-diyl)bis(chlorobenzene) (DDE)
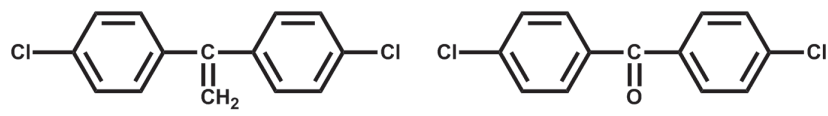

4,4'-(2-chloroethene-1,1-diyl)bis(chlorobenzene) (DDMU)

4,4'-(ethene-1,1-diyl)bis(chlorobenzene) (DDNU)

bis(4-chlorophenyl)methanone (DBP)
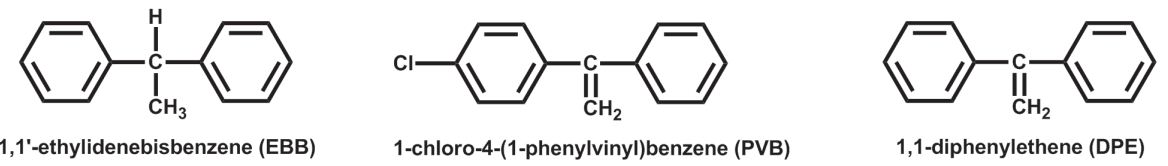

1,1-diphenylethene (DPE)

Fig. 3. Structures, names, and shorthand designations for DDT and its degradation products. 
that the cathodic peak associated with reductive conversion of the $-\mathrm{CCl}_{3}$ group to a $-\mathrm{CHCl}_{2}$ moiety is absent. Due to the longer time scale of bulk electrolyses, elimination reactions that follow electron-transfer events are responsible for the production of DDE, DDMU, and DDNU.

In subsequent research [59], the cobalt(I) salen-catalyzed reduction of DDT was found to be more complete with less energy input, and more than $90 \%$ of DDT was reduced to DDNU. Recently, we employed electrogenerated nickel(I) salen as a catalyst for the reduction of DDT; it was discovered that reductive cleavage of the carbon-chlorine bonds leads to radical intermediates that eventually produce primarily DDNU in a three-electron process, along with some total dechlorination of DDT to afford DPE [60]. In addition, our group has investigated the use of a silver cathode to reduce DDT in organic media. It has been discovered that the three carbon-chlorine bonds of the chlorinated ethyl group of DDT are reduced at less negative potentials at silver than at glassy carbon in DMF (as well as in $\mathrm{CH}_{3} \mathrm{CN}$ and DMSO), and that dechlorination of the aryl moieties is possible. Bulk electrolyses in DMF at the potential corresponding to the most negative cyclic voltammetric peak result in formation of the completely dechlorinated products DPE and EBB to an extent of $75 \%$. When $1.0 \mathrm{M}$ water was added to DMF as a proton donor, EBB was obtained in essentially $100 \%$ yield.

Polychlorinated benzenes. Work has been done to examine the reduction of polychlorinated benzenes, which cause many serious health problems including cancer as well as liver, kidney, and thyroid toxicity [61]. Di-, tri-, and tetrachlorobenzenes were studied in our laboratory to determine their electrochemical behavior at carbon cathodes in DMF-TMAP; cyclic voltammograms for reduction of these species show peaks for sequential cleavage of carbon-chlorine bonds, and bulk electrolyses confirmed that removal of each halide requires two electrons and that benzene is the final product [62]. Electrocarboxylation of di-, tri-, tetra-, and hexachlorobenzenes at zinc cathodes was accomplished by Chaussard et al. [63] and by Golinske et al. [64] to produce mono- and dicarboxylic acids.

Reduction of the persistent organic pollutant, 1,2,3-trichlorobenzene, at various sintered noble-metal cathodes was investigated by Miyoshi et al. [65]; depending on the choice of cathode material, $70-90 \%$ dechlorination was achieved. Subsequent research was directed at minimizing the amount of solvent and decreasing the time for dechlorination $[66,67]$. Guena and coworkers [68] studied the direct and catalytic reduction of 1,2,3and 1,2,4-trichlorobenzene at several electrode surfaces $(\mathrm{C}, \mathrm{Fe}$, $\mathrm{Pb}, \mathrm{Hg}$, and $\mathrm{Pt}$ ) and determined that product distributions are only slightly affected by cathode material. An early patent by the Dow Chemical Company determined that 1,2,3,4-tetrachlorobenzene could be selectively converted to 1,2,3-trichlorobenzene in ethanol containing ammonium chloride and $\mathrm{TMACl}$ at lead or mercury cathodes [69]. Various cathode materials ( $\mathrm{Pt}$, $\mathrm{Ni}, \mathrm{Ti}, \mathrm{Pb}, \mathrm{Cu}$, carbon cloth, and palladium-modified carbon cloth) were employed by Kulikov et al. [70] and by Plekhanov et al. [71] for the stepwise dechlorination of 1,2,3,5-tetrachlorobenzene.
Electrochemical degradation of hexa-, penta-, and tetrachlorobenzenes was investigated by Lee et al. [72] and by Sugimoto et al. [73] in DMF-TEAP at Pt, Au, or C cathodes in the presence of oxygen; electrogenerated superoxide ion mediates the reduction of these compounds to give the corresponding alcohol with the loss of a single chloride ion. Catalytic reduction of hexa- and pentachlorobenzene by cobalt(I) salen, electrogenerated at a glassy carbon cathode in $\mathrm{DMF}-\mathrm{TMABF}_{4}$, was studied in our laboratory [74]. Similar work was performed by Páramo-Garcío et al. [75,76], who focused on the direct and cobalt(I) salen-catalyzed reduction of hexachlorobenzene at a carbon electrode in a $\mathrm{CH}_{3} \mathrm{CN}-\mathrm{TBAP}$ medium.

Simagina et al. $[77,78]$ employed carbon-supported palladium and nickel catalysts for the electrodegradation of hexachlorobenzene to dichlorobenzenes, chlorobenzene, and benzene; in addition, this research group examined the kinetics of hydrodechlorination of hexachlorobenzene on carbon surfaces modified with catalysts such as $\mathrm{Ni}, \mathrm{Ni}-\mathrm{Pd}$, and $\mathrm{Cu}-\mathrm{Pd}[79,80]$. Direct reduction of hexachlorobenzene at lead and mercury cathodes in methanol, methanol-water, and aqueous micellar solutions of Triton-SP 175 was conducted by Merica et al. [81-83] to yield predominantly tri- and dichlorobenzenes. Some other investigations of the electrochemical dechlorination of chlorinated benzenes are notable: (a) electrolytic degradation of hexachlorobenzene in contaminated soil [84,85]; (b) cyclic voltammetric reduction of hexachlorobenzene at mercury [86,87]; (c) bulk electrolysis of all chlorinated benzenes [88]; and (d) mechanistic studies of the electroreduction of hexachlorobenzene at mercury $[89,90]$.

Lindane. $\gamma$-Hexachlorocyclohexane (lindane, 4) causes damage to mammalian nervous systems, and was banned by the Stockholm convention in 2007.

Several publications pertain to the direct reduction of lindane to afford benzene at various cathodes, including mercury, copper-coated steel, carbon cloth, zinc-modified carbon cloth, and electrodeposited films of palladium or ruthenium [91-97]. Using the naphthalene radical-anion, electrogenerated in DMF at a glassy carbon cathode, Matsunaga and Yasuhara [98] achieved nearly quantitative dechlorination of lindane. Some recent work has focused on the development of electroanalytical sensors for lindane in aqueous systems $[99,100]$.

In our laboratory the electrochemical behavior of lindane at a glassy carbon electrode in DMF has been investigated [101]. Cyclic voltammograms exhibit two cathodic peaks, the first attributable to reduction of lindane itself, and the second due to chlorobenzene (a minor product). Controlled-potential electrolyses conducted just past the first peak resulted in the

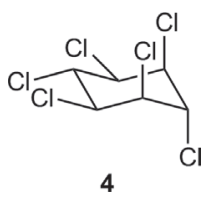

Fig. 4. Structure of $\gamma$-hexachlorocyclohexane (lindane, 4). 
formation of benzene (80-93\%), along with a small quantity of chlorobenzene. However, bulk electrolyses conducted beyond the second cathodic peak result in complete dechlorination. These findings are in accord with theoretical computations, which support the proposed mechanism.

In a subsequent study [102], our group employed silver cathodes to reduce lindane in various solvents. A combination of one- and two-electron processes has been proposed to account for benzene as the major product. Dechlorination is essentially complete in DMF and in mixtures of water with $\mathrm{DMF}, \mathrm{CH}_{3} \mathrm{CN}$, and ethanol, whereas some chlorobenzene was detected in pure ethanol and $\mathrm{CH}_{3} \mathrm{CN}$.

Triclosan and methyl triclosan. Substantial work has been done concerning the electrochemical reduction of 5-chloro-2-(2,4dichlorophenoxy)phenol (triclosan, 5), which was once a popular pesticide. Reports have indicated, however, that triclosan affects the endocrine system and causes cancer [103]. Pemberton and Hart [104] employed screen-printed carbon electrodes to study the voltammetric behavior of $\mathbf{5}$ in a diethanolamine buffer and to develop an analytical method for its detection in toothpastes and mouthwashes. Similar research, dealing with reduction of $\mathbf{5}$ at a mercury cathode, was conducted by Safavi and co-workers $[105,106]$. Direct reduction of $\mathbf{5}$ at carbon fiber cathodes in aqueous buffer solutions and in methanol or DMF media was shown to afford two products, chlorobenzene and 2-phenoxyphenol [107]; later, the same electrodes were employed to detect 5 in urine and serum samples [108].

In our laboratory [109], cyclic voltammograms for reduction of $\mathbf{5}$ at a glassy carbon cathode in $\mathrm{DMF}-\mathrm{TBABF}_{4}$ exhibited three irreversible cathodic peaks, each attributed to cleavage of a carbon-chlorine bond; bulk electrolyses always afforded 5-chloro-2-(4-chlorophenoxy)phenol as the major product (49-73\%), regardless of the chosen potential. In yet unpublished research, our group has sought to optimize the degradation reaction by employing silver cathodes and by modifying the structure of 5 to form 2,4-dichloro-1-(4-chloro2-methoxyphenoxy)benzene (methyl triclosan, 6). At a silver cathode, $\mathbf{6}$ is easier to reduce than $\mathbf{5}$ by approximately 80 $\mathrm{mV}$; bulk electrolysis of $\mathbf{6}$ at a silver gauze electrode affords 1-(4-chlorophenoxy)-2-methoxybenzene (39-63\%) along with unreduced starting material. Interestingly, electrochemical degradation of 6 at a reticulated vitreous carbon cathode leads to a mixture of 4-chloro-1-(4-chlorophenoxy)-2-methoxybenzene, 4-chloro-2-methoxy-1-phenoxybenzene, 1-methoxy-2phenoxybenzene, anisole, and phenol.

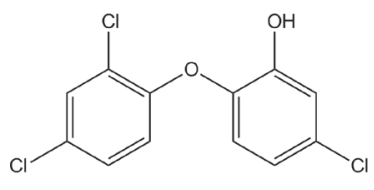

5

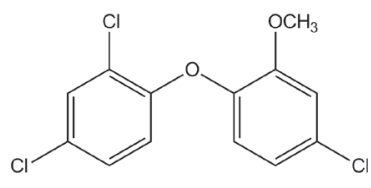

6
Fig. 5. Structures of 5-chloro-2-(2,4-dichlorophenoxy)phenol (triclosan, 5) and 2,4-dichloro-1-(4-chloro-2-methoxyphenoxy)benzene (methyl triclosan, 6).

\section{Triazines and Benzonitriles}

Atrazine (7), banned from use in the European Union, is presently the most widely applied herbicide in North America. Although dangers of its use are debatable, its electrochemical behavior is of interest. Early investigations explain that 7 functions by interrupting electron transport to plastohydroquinone in photosynthesis II. Electrochemical reduction of atrazine (7) and tert-butylazine (8) has been studied with the aid of mercury electrodes in air-free aqueous media [110]; it has been concluded that two-electron reduction of the azine ring leads to a dechlorinated product and, in solutions with high proton availability, unethylated products have been detected.

A mechanistic study [111] of the reductions of atrazine (7), simazine (9), and propazine (10) at mercury suggests the occurrence of a two-electron process. Reduction of triazines, as well as some diazines, at a mercury electrode has been explored in acidic media; a reversible ring opening was considered, which allowed for the polarographic detection of maleic hydrazide, sulfometuron, methyl hexazinone, metamitron and metribuzin [112]. Other research groups [113-115] have examined postelectrolysis solutions by means of NMR techniques to confirm the presence of a triazine ring-opened intermediate as well as a dechlorinated product. Atrazine (7) has been reduced at carbon and solid amalgam electrodes [116], and electrochemical sensors have been designed to determine the amount of triazine pesticides in environmental aqueous samples $[117,118]$.

Halogenated benzonitriles, similar to atrazine, have been used as herbicides to inhibit electron transfer at the photosystem II receptor. Although reduction and photodegradation of halogenated benzonitriles have been studied previously [119], exact mechanisms were only recently elucidated. Sokolová and coworkers [120] carried out bulk electrolyses of ioxynil (11), bromoxynil (12), and chloroxynil (13) in DMSO, which resulted in the removal of one halogen atom from each compound.

\section{E. Pyrethroids}

Pyrethroid insecticides have recently been commercially distributed for both household and agricultural needs. These compounds are synthetic insecticides whose chemical structures are adapted from those of natural pyrethrins. Although these insecticides pose little threat in small doses, exposure to significant amounts of these compounds may cause respiratory problems, neurotoxin effects, and temporary illness [121]. An

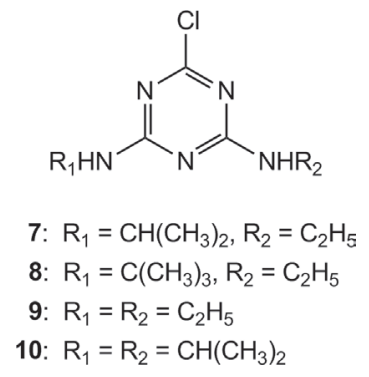

Fig. 6. Structures of atrazine (7), tert-butylazine (8), simazine (9), and propazine (10). 
<smiles>[X]c1cc(C#N)cc([X])c1O</smiles>

11: $X=1$

12: $X=B r$

13: $\mathrm{X}=\mathrm{Cl}$

Fig. 7. Structures of ioxynil (11), bromoxynil (12), and chloroxynil (13).

early investigation by Jehring et al. [122] focused on the electrochemical reduction of deltamethrin (14) at mercury in both DMSO and aqueous methanol; a cyclic voltammogram displayed sequential cathodic peaks corresponding to cleavage of each carbon-bromine bond.

Coomber and co-workers [123-126] used cyclic voltammetry and controlled-potential electrolysis to examine the reduction of a number of halogenated pyrethroid insecticides at carbon or mercury cathodes in $\mathrm{CH}_{3} \mathrm{CN}$. Electrochemical reduction of other chlorinated pyrethroid insecticides has been studied by Sreedhar et al. $[127,128]$. Investigations of the reduction of $\lambda$-cyhalothrin, cypermethrin, and deltamethrin at a mercury electrode were carried out by Oudou and colleagues $[129,130]$, and a similar study was conducted by Naidu et al. [131] on the electrochemical behavior of fenvalerate.

\section{Flame Retardants}

Brominated flame retardants comprise a class of compounds commonly used in manufactured goods such as textiles, furniture, electronics, and plastics [132-135]. Due to the wellknown propensity of these halogenated compounds to accumulate ubiquitously in all media, including humans and wildlife $[135,136]$, brominated flame retardants are categorized as "persistent organic pollutants" (POPs) [137] and have been banned or have had their production ceased [135]. Environmental studies have focused primarily on three major groups: brominated phenols, polybrominated biphenyls and diphenyl ethers, and hexabromocyclododecanes [132]. Dehalogenated forms of these compounds pose a smaller threat to the environment; thus, electrochemistry is an important tool for remediation. In comparison to the large number of flame retardants in existence, relatively few electrochemical studies of these compounds have been reported. For the papers found in the

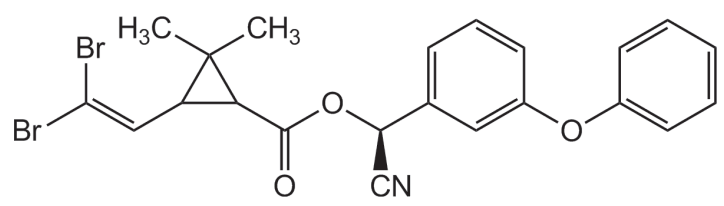

14

Fig. 8. Structure of deltamethrin (14). literature, the primary focus is remediation via reductive cleavage of the carbon-bromine bonds, which can often be achieved under relatively mild conditions in comparison with other remediation strategies.

\section{A. Brominated Phenols}

Electrochemical methods that employ silver cathodes have been studied for the dehalogenation of brominated phenols. Using controlled-potential electrolysis in $\mathrm{CH}_{3} \mathrm{CN}-\mathrm{TEAP}$, Rondinini and co-workers [138] employed silver cathodes to examine the outcomes of changing the number and position of bromine atoms on the phenol moiety. For example, reductions of meta- and para-bromophenol showed little or no difference in product distributions. On the other hand, a comparison of the reductions of 2,6-dibromophenol and 2,4-dibromophenol demonstrated that an ortho-bromine is more difficult to remove than a para-bromine. In addition, when the reduction of 2,4,6tribromophenol was explored in $\mathrm{CH}_{3} \mathrm{CN}$ and in a $\mathrm{CH}_{3} \mathrm{CN}-\mathrm{H}_{2} \mathrm{O}$ mixture, less debromination was achieved in the mixed solvent system.

Fiori et al. [139] used both constant-potential and constant-current methods to investigate the electrochemical reduction of several polybrominated phenols in $\mathrm{CH}_{3} \mathrm{CN}, \mathrm{H}_{2} \mathrm{O}$, and a mixture of these two solvents. Once again, the success of the debromination was strongly correlated with the positions of the bromine atoms on the aromatic ring. Reduction of polyhalogenated phenols has also been studied by Xu et al. [140,141], who were interested in how the efficiency of the debromination process depends on whether one uses a polished silver cathode or a silver cathode surface-roughened by means of repetitive electrochemical oxidation or reduction; better response was obtained with the latter electrode.

\section{B. Polybrominated Biphenyl and Diphenyl Ether}

Among all possible congeners of brominated biphenyls, the three most commonly used as flame retardants are hexabromo-, octabromo-, and decabromobiphenyl [142]. Surprisingly, no studies involving the electrochemical debromination of these three flame retardants have been reported. On the other hand, Rusling and co-workers have determined standard potentials for the reduction of 4,4'-dibromobiphenyl and 3,3',5,5'-tetrabromobiphenyl at a hanging mercury drop electrode in DMFTBAI [143] and for the reduction of 4,4'-dibromobiphenyl and $2,2^{\prime}, 5,5^{\prime}$-tetrabromobiphenyl at a mercury film electrode in a bicontinuous microemulsion [144].

Because of their extensive use in household products, penta-, octa-, and decabromodiphenyl ethers are the most commonly EPA-monitored polybrominated diphenyl ethers [142]. However, only a few publications have dealt with the electrochemical remediation of brominated diphenyl ethers. Constant-current electrochemical reduction of 4-bromodiphenyl ether and 4,4'dibromodiphenyl ether at a reticulated vitreous carbon cathode in a methanol-water mixture stirred with solid catalyst particles (palladium on aluminum) results in the production of diphenyl ether in yields of $48 \%$ and $35 \%$, respectively [145]. In another study, Konstantinov and co-workers [146] found that constant- 
current electrochemical reduction of decabromodiphenyl ether in tetrahydrofuran at a platinum black electrode gives a mixture of partially debrominated products, ranging from tetra- to monobromodiphenyl ether.

Recent research in our laboratory [147] was directed toward a study of the electrochemical reduction of decabromodiphenyl ether (DBDE) at both glassy carbon and silver cathodes in DMF and DMSO by means of cyclic voltammetry and controlled-potential electrolysis. With either electrode material, the most diphenyl ether was produced in bulk electrolyses performed in DMSO, but significant amounts of brominated compounds (mono- to nonabromodiphenyl ether) were detected. Furthermore, when silver was employed as the cathode and DMSO was the solvent, unreduced decabromodiphenyl ether (42\%) was still present at the end of a bulk electrolysis. On the other hand, with both cathode materials, dibromodiphenyl ethers were the only brominated products, along with phenol, found when DMF was used as the solvent.

\section{Hexabromocyclododecane}

Hexabromocyclododecane (HBCD), the most employed cyclic aliphatic brominated flame retardant [148], has recently been the subject of several electrochemical remediation studies. Using cyclic voltammetry and controlled-potential (bulk) electrolysis, our group has investigated the direct reduction of HBCD at glassy carbon and silver cathodes [149] as well as its catalytic reduction by nickel(I) salen electrogenerated at vitreous carbon electrodes in DMF-TMABF 4 . Direct reduction of $\mathrm{HBCD}$ at a silver electrode occurs at a potential $900 \mathrm{mV}$ more positive than at a glassy carbon electrode. Bulk electrolysis of a $2.0 \mathrm{mM}$ solution of HBCD at both electrodes results in complete debromination to afford isomers of 1,5,9-cyclododecatriene and cyclododecane-1,5-dien-9-yne. However, direct reduction at carbon is the preferred remediation method for higher concentrations of $\mathrm{HBCD}$; in fact, for concentrations of $\mathrm{HBCD}$ greater than $2 \mathrm{mM}$, direct bulk reduction at silver leads to incomplete debromination. Nickel(I) salen-catalyzed reduction of HBCD can achieve complete debromination in $3 \mathrm{~h}$ or less for concentrations of HBCD below $20 \mathrm{mM}$.

Baron and associates $[150,151]$ examined the direct reduction of HBCD at a glassy carbon cathode in DMF as well as the reduction of HBCD when procatalysts, specifically cobalt tetraphenylporphorin (CoTPP) and cobalamin, were added to the system. In the presence of CoTPP, the catalytic reduction of $\mathrm{HBCD}$ was more than $1 \mathrm{~V}$ easier than the direct reduction. In very recent research, Romańczyk and co-workers [152] have employed tetraphenylporphyrin as a procatalyst for the reduction of $\mathrm{HBCD}$ in $\mathrm{DMF}-\mathrm{TBABF}_{4}$.

\section{Miscellaneous Compounds}

Halogenated anhydrides and esters, such as tetrabromophthalic anhydride (a flame retardant commonly used in foams, papers, textiles, epoxides, and wool), comprise what we refer to as miscellaneous compounds. Although the main purposes of studies reported in the remaining paragraphs of this section do not entail the development of a remediation technique, these papers are germane to the electrochemical behavior of some interesting compounds. Luca et al. [153] investigated the cyclic voltammetric behavior of tetrabromo- and tetrachlorophthalic anhydride at a glassy carbon electrode in DMFTEAP. Electrochemical reduction of brominated and chlorinated derivatives of phthalic anhydrides and phthalic imides was employed by Troll and co-workers [154] for the synthesis of 1,3-bis(trimethyl)silyloxy-substituted isobenzofurans and isoindoles. Goulart et al. [155] observed the electroreduction of halogenated esters of fumaric acid at both mercury and carbon electrodes in DMF and $\mathrm{CH}_{3} \mathrm{CN}-\mathrm{H}_{2} \mathrm{O}$ media.

\section{E. Sensors for Flame Retardants}

In addition to remediation techniques, the need for inexpensive, real-time, and selective sensors for flame retardants has sparked research in environmental electrochemistry. Of the three examples mentioned below, two sensors are based on molecularly imprinted polymers (MIPs), which are films prepared in the presence of a target molecule that, after being removed, leaves behind a complementary cavity in the film, thus enabling selective detection of a target species. Belbruno [156] has a patent pending that calls for MIP electrodes to detect a variety of target molecules such as chlorinated solvents, organophosphates, methylsiloxanes, endocrines, estrogens, organic bromides, and decabromodiphenyl ether. A specific MIP electrochemical sensor for the indirect detection of tetrabromobisphenol A in natural water samples has been developed by Chen and associates [157]. Lin and co-workers [158] have described a selective, precise, reproducible, and stable poly(dopamine)-coated, gold nanocluster-functionalized electrochemical immunosensor for the detection and determination of brominated flame retardants such as 3-bromobiphenyl.

\section{Disinfection By-Products}

Disinfection of water by chlorination was patented by Lieds in 1898 , and today this process remains the most dominant method for the purification of water [159]. Although chlorination offers many great qualities, it has drawbacks. When chlorine reacts with natural organic matter, dissolved or suspended in water, numerous halogenated disinfection by-products (DBPs) are formed, including trihalomethanes (THMs) and haloacetic acids (HAAs). Ghernaout and Ghernaout [159] state that more than 700 DBPs arising from the chlorination of water have been reported and that this total might account for only one half of all halogenated organic compounds produced via chlorination. A review chapter by Richardson and Postigo [160] summarizes up-to-date information about regulated DBPs (trihalomethanes, haloacetic acids, bromate, and chlorite) as well as numerous families of emerging (nonregulated) DBPs.

Trihalomethanes (THMs) and haloacetic acids (HAAs) account for the majority of the known DBPs and are among the most environmentally relevant; the family of THMs includes $\mathrm{CHCl}_{3}, \mathrm{CHCl}_{2} \mathrm{Br}, \mathrm{CHClBr}_{2}$, and $\mathrm{CHBr}_{3}$, whereas the HAAs are $\mathrm{ClH}_{2} \mathrm{CO}_{2} \mathrm{H}, \mathrm{Cl}_{2} \mathrm{HCO}_{2} \mathrm{H}, \mathrm{Cl}_{3} \mathrm{CO}_{2} \mathrm{H}, \mathrm{BrH}_{2} \mathrm{CO}_{2} \mathrm{H}$, and $\mathrm{Br}_{2} \mathrm{HCO}_{2} \mathrm{H}$. Among the four THMs, chloroform is the most 
frequently detected volatile organic compound in the ground water supply of the United States [161]. Trihalomethanes and haloacetic acids are both widespread environmental pollutants with significant effects such as toxicity, mutagenicity, carcinogenicity, and teratogenicity [162-165]. In this section, we focus on the reduction of THMs and HAAs at a variety of cathode materials as a means of both detection and remediation.

\section{A. Trihalomethanes (THMs)}

Reduction of chloroform (a model trihalomethane) at a classic mercury drop cathode has been studied by means of squarewave and cyclic voltammetry in water, methanol, and DMSO. For each of these solvents, only a single cathodic peak is observed; because of the strong interaction of chloroform with DMSO, its use provides the highest sensitivity and the lowest detection limit for the determination of chloroform. Reduction of chloroform was determined to be a two-electron process that leads to the formation of dichloromethane. Presumably, this two-electron process could be repeated at more negative potentials until methane is formed, but the potentials for further reduction of dichloromethane are beyond the potential window of typical solvent-electrolyte systems. Under similar conditions, the electrochemical reduction of bromoform gives rise to three voltammetric waves, each corresponding to reductive cleavage of a carbon-bromide bond, which results in the formation of methane as the final product [166].

Interest in the electrochemistry of THMs intensified in the 1990s. Some effort was aimed at the electrooxidation of THMs at various anode materials in aqueous media [167], but the focus remained on reduction. Studies were performed to compare the current efficiencies for the reduction of chloroform and dichloromethane at a variety of cathode materials, palladium and silver being most efficient $[168,169]$. Isse and co-workers $[170,171]$ reported that the potential for reduction of chloroform shifts to a more positive value by approximately $600 \mathrm{mV}$ when silver instead of glassy carbon is used as a cathode in DMF. An extensive study of the reduction of chloroform and dichloromethane in various solvents at carbon and silver as well as silver-bismuth and silver-tin alloys was reported by Rondinini and Vertova [172]; in general, reductions at silver alloys exhibited more positive peak potentials than those at carbon, whereas cathodic peak potentials at elemental silver were even more positive. In a potentiostatic electrolysis of chloroform at a silver cathode in a $1: 1 \mathrm{CH}_{3} \mathrm{CN}-\mathrm{H}_{2} \mathrm{O}$ medium, the products are chloromethane and methane [172]. Durante and co-workers [173] observed that chlorinated methanes are much more readily reduced in DMF at silver than at carbon, and they reported that the reduction proceeds better in the presence of a proton donor (acetic acid). In our laboratory, potentials for reduction of bromoform, chloroform, bromodichloromethane, dibromochloromethane, and their less-halogenated products at silver cathodes in an aqueous medium have been determined [174].

Benefits of water as a co-solvent with $\mathrm{CH}_{3} \mathrm{CN}$ for reductions of chloroform and dichloromethane were demonstrated by Fiori and associates [175]; they found that chloroform is completely reduced at a silver electrode in a $1: 1 \mathrm{CH}_{3} \mathrm{CN}-$ $\mathrm{H}_{2} \mathrm{O}$ medium, whereas incomplete reduction was seen in pure $\mathrm{CH}_{3} \mathrm{CN}$. Radjenović et al. [176] investigated the use of a resinimpregnated graphite electrode for the reductive electrodegradation of trihalomethanes. In our publication dealing with the determination of THMs in drinking water [174], it was reported that reduction of bromoform could be accomplished in $1000 \mathrm{~s}$ at a silver cathode in an aqueous medium with a coulometric $n$ value of $6.34 \pm 0.16$, which confirms that cleavage of each carbon-bromine bond is a two-electron process.

Several studies by Sonoyama and co-workers [177-179] describe metal-impregnated carbon-fiber electrode flow systems for the removal of trihalomethanes from drinking water. In one study [177], it was shown that zinc- and silver-impregnated fibers could completely reduce chloroform in an aqueous medium, whereas dichloromethane was only partially degraded at silver-impregnated carbon fibers. On the other hand, a column electrode composed of copper powder was found to decompose dichloromethane completely [178]. In later work [179], a flow-through cell that incorporated a silver-impregnated, spiral platinum wire-activated carbon cathode was utilized for the dehalogenation of chloroform, bromodichloromethane, dibromochloromethane, and bromoform, but the reduction of dichloromethane proved to be inefficient.

\section{B. Haloacetic Acids (HAAs)}

In the 1950s, Elving and his students $[180,181]$ explored the electrochemical reduction of bromoacetic acids and chloroacetic acids at mercury cathodes in aqueous media. More recently, Korshin and Jensen [182] found that chloroacetic acids are more difficult to reduce than their bromoacetic acid counterparts at a copper electrode. Ordaz and co-workers [183] studied the reduction of organohalides, including dichloroacetic acid and trichloroacetic acid, at chemically modified electrodes made by inbedding hemin in a film of didodecyldimethylammonium bromide and by preparing films of electropolymerized cobalt porphyrin and cobalt salen.

\section{Detection of THMs and HAAs}

Due to the compound-specific potentials for reduction of THMs at various cathode materials, it should be possible to devise low-concentration sensors to monitor the presence of DBPs. For example, Carvalho and associates [184] designed polymercoated gold electrodes to detect chloroform (as a representative DBP) in aqueous media, and it is reasonable to conclude that this approach could be extended to monitor other halogenated DBPs. Dobson et al. [185] indicated that haloalkanes have a limit of detection of $5 \mu \mathrm{M}$ at porphyrin-modified electrodes. To date, one of the most sensitive sensors for organohalides is a zinc metal-polytetrafluoroethylene particle (PTFE) composite-plated electrode, with a detection limit of $0.1 \mathrm{nM}$, that was designed by Wiyaratn and co-workers [186-188]. In our own investigation [174] of the determination of THMs in drinking water by means of stripping analysis with silver electrodes, detection limits of $3.0 \mu \mathrm{g} \mathrm{L}^{-1}(12 \mathrm{nM})$ and $6.0 \mu \mathrm{g} \mathrm{L}-1(50 \mathrm{nM})$ for bromoform and chloroform, respectively, were achieved. 
New electrode systems have been utilized as sensors for HAAs. Using a gold electrode filmed with polynickel(II)-tetrasulfonated phthalocyanine, Altamar and associates [189] determined chloro-, dichloro-, and trichloroacetic acids in aqueous alkaline solutions by means of differential pulse voltammetry. Suedee et al. [190] designed a molecularly imprinted polymer (MIP) as a specific receptor for trichloroacetic acid; this MIP was incorporated into an electrochemical sensor for the detection and quantitation of trichloroacetic acid.

By monitoring the change in current at a potential corresponding to reduction of HAAs, when a water sample flows through a conducting-polymer-membrane electrode, one can detect these pollutants [191]; unfortunately, this approach requires a chromatographic separation before the measurement step. Wei and co-workers [192] used a carbon electrode, surface-modified with $\mathrm{C}_{60}$-[dimethyl-( $\beta$-cyclodextrin) $]_{2}$ encased in Nafion ${ }^{\circledR}$, in a $\mathrm{CH}_{3} \mathrm{CN}-\mathrm{H}_{2} \mathrm{O}$ medium to correlate the measured current with the concentration of HAAs in a sample. Square-wave voltammetry has been utilized for the detection of trichloroacetic acid in an aqueous solution at an electrode consisting of silver nanoparticles coated onto multi-walled carbon nanotubes [193].

\section{Electrochemical Behavior of Other DBPs}

Although THMs and HAAs together represent about $25 \%$ of the total of halogenated organic compounds quantitated after disinfection of water by chlorine, many more DBPs remain beyond these two classes; the list includes halogenated aldehydes, ketones, nitriles, amides, furanones, pyrroles, quinones, and nitromethanes. Moreover, the above-mentioned group of THMs and HAAs excludes all of the possible iodinated THMs and HAAs that might be present in drinking water. Indeed, $70 \%$ of the halogenated DBPs are still of unknown identity. Some of these unidentified compounds are thought to be halogenated contamination products, such as pharmaceuticals, personal care products, estrogen, pesticides, and surfactants $[159,160]$. Due to the numerous DBPs in these other classes of halogenated pollutants, publications dealing with them have not been incorporated into this review. Nonetheless, the electrochemical behavior of some of these species has been examined; for example, Radjenović and co-workers [176] report the reduction and substantial degradation of haloacetonitriles, halopropanones, chloral hydrate, and trichloronitromethane at their resin-impregnated graphite electrode.

\section{Future Directions}

As revealed in the preceding sections of this review, past strategies for the electrochemical remediation of halogenated organic pollutants in our laboratory have involved either direct or mediated reduction at glassy carbon electrodes along with direct reduction at silver cathodes. On the other hand, the electrochemistry of organic halides, including some that are environmental pollutants, at other cathode materials has been reported with promising results [194-200]. In addition, future directions for environmental electrochemistry could en- tail modification of an existing electrolysis method to include or allow (a) industrial scale-up, (b) scale-down for sensor technologies, (c) flow-by or flow-through cells, (d) employment of ionic liquids, and (e) electrocarboxylation. At the end of this section, we will call attention to the fact that many halogenated organic pollutants remain uninvestigated by electrochemical means.

For remediation purposes, cathode materials should provide high catalytic activity for reduction of an organic halide and should be cost effective. Bellomunno et al. [194] performed cyclic voltammetry with silver, copper, gold, lead, mercury, bismuth, and tin electrodes for the reduction of four organic bromides; shifts in peak potentials, with respect to those observed at glassy carbon, were found to be in accord with the relative electrocatalytic activity of each metal. Select organic bromides were found to undergo an electrocatalytic reduction at mercury, copper, gold, and lead comparable to what is seen with silver. Isse and co-workers $[195,196]$ explored the reduction of various organic chlorides at glassy carbon, silver, copper, and palladium; the extent of catalysis was found to be favorable for copper, palladium, and silver, in a fashion similar to that observed by Bellomunno and co-workers [194]. In addition, Simonet [197-200] has produced thought-provoking work that concerns smooth palladium and palladized surfaces of platinum, glassy carbon, gold, copper, and nickel; reductions of various alkyl iodides at these surfaces all demonstrate catalysis. Surprisingly, peak potentials for the reduction of 2-iodopropane, 1-iodohexane, and 1-iodo-3-phenylpropane at palladized gold are shifted to less negative values than at silver [198]. By analogy to palladized surfaces, it is tantalizing to imagine other bimetallic surfaces that would be more economical and that might engender new cathodic reactions.

In addition to exploration of new polycrystalline cathode materials, it would be worthwhile to investigate the effect of exposed facets of single crystals on the catalytic reduction of halogenated organic pollutants, perhaps as a way to tailor a more efficient cathode for detection and remediation purposes. Ardizzone et al. [201] investigated the behavior of organic iodides and bromides at polycrystalline as well as monocrystalline silver (111), (110), and (100). For polycrystalline silver, catalytic activity increases with surface roughness; however, for monocrystalline silver, electrocatalytic activity increases with atomic density, $(111)>(100)>(110)$, for all organic halides studied, except an aryl bromide and bromotoluene, where the trends are reversed. Hoshi and co-workers [202] observed that the faradaic efficiency for reduction of chloroform to methane increases in the same order.

Nanoparticles (NPs) are attractive for use in remediation processes because of their large surface-to-volume ratio; however, knowledge of the effects of cathode material, morphology, and size is necessary to design cost-effective NPs for remediation of halogenated organic pollutants. Shape and type of support are two aspects studied by Minguizzi et al. [203]; these workers found better catalytic reduction of chloroform at electrosynthesized silver NPs on Vulcan ${ }^{\circledR}$ XC72-R that was pretreated with nitric acid, filtered, washed, and dried than at 
silver nanocubes prepared by mediated polyol reduction on untreated Vulcan ${ }^{\circledR}$ XC72-R.

For remediation purposes, it is vital to move from a laboratory bench to a large industrial scale in order to accommodate large quantities of polluted materials, such as lake and river water. Most important is the design of an electrochemical reactor that fulfills several requirements: (a) high active electrode area per volume, (b) high current efficiency, (c) efficient mass transport, and (d) low cell voltage; several review articles discuss a variety of reactor and cell designs [204-207]. He and co-workers [207] achieved reductive dehalogenation of aqueous-phase chlorinated hydrocarbons in a two-dimensional electrochemical reactor composed of a cylindrical porous-copper foam cathode separated from a carbon-cloth anode by a proton-exchange membrane; carbon tetrachloride was dechlorinated with $80 \%$ efficiency in $10 \mathrm{~min}$.

On the other hand, scale-down is pertinent to the design of inexpensive and efficient electrochemical sensors for the detection and measurement of environmental pollutants. Examples of electrochemical sensors can be found in the literature, a few of which are mentioned in the sections of this review that deal with flame retardants and DBPs. Popovtzer et al. [206] developed a bacterial-based biosensor, which provides physiological information as well as identification and quantitation of pollutants. Each biochip sensor was composed of eight miniaturized electrochemical cells, with gold working and counter electrodes and a silver-silver chloride reference electrode. At a constant applied potential, the presence of a toxin transcribes a promoter gene coupled to a reporter gene, which are indirectly monitored by $\beta$-galactosidase activity arising from electrooxidation of $p$-aminophenol (that is formed from $p$-aminophenyl$\beta$-galactopyranoside). Protein damage by ethanol as well as membrane damage by exposure to phenol created a response from the appropriate promoter in an induction period of $10 \mathrm{~min}$, which is much faster than similar methods that utilize optical detection.

Flow-by and flow-through cells can improve the efficiency of already established and conventional batch techniques in electrochemistry. Information pertaining to planar and cylindrical geometries of flow cells has been presented by Lunte et al. [208]. Although flow-by cells are commercially available, many laboratories undertake their own fabrication, as revealed in a paper by Noyhouzer and co-workers [209]. Other examples of detection by flow-by methods have been reported by Chen and associates [210], Richter et al. [211], and Naseri and co-workers [212]. In comparison with flow-by methods, flow-through systems with porous electrodes for detection and remediation of pollutants offer improved efficiencies. An electrochemical flow-through cell was used by Cacho et al. [213] to pre-concentrate samples prior to measurements by means of atomic absorption spectroscopy.

Ionic liquids, in place of traditional organic solvents containing an electrolyte, have the possibility of making an electrochemical remediation process more environmentally friendly. Literature relevant to this subject continues to expand at a rapid pace [214-218]. Reports of studies that involve direct or cata- lytic reduction of carbon-halogen bonds in ionic liquids include the following: (a) work by Bhat et al. [219] concerning the mechanism of reduction of chloroform in traditional solvents and in an ionic liquid; (b) research by Titov and co-workers [28] and by Doherty et al. [31] on the dehalogenation of CFCs in an ionic liquid; (c) a paper [220] describing the nickel(I) salencatalyzed reductions of iodoethane and CFC-113 in 1-butyl3-methylimidazolium tetrafluoroborate; and (d) a publication by Shen and associates [221], who studied the cobalt(I) salencatalyzed reduction of organic bromides. Several electrochemical studies of the reduction of organic halides in ionic liquids containing $\mathrm{CO}_{2}$ have been carried out with attractive results from the perspective of remediation [222-225].

Electrocarboxylation in traditional organic solvents is another area worthy of more exploration; in principle, such an approach can lead simultaneously to the useful remediation of halogenated pollutants and to the consumption of an abundant greenhouse gas. Electrocarboxylated products can possess substituents that are not accessible by ordinary organic methodology; moreover, electrocarboxylation can introduce more than one carboxylate moiety onto a starting material. SánchezSánchez et al. [226,227] provide excellent overviews of the electrocarboxylation of organic halides. To increase the yields of carboxylated products and to decrease the potentials needed to reduce a variety of halogenated species, there have been investigations of solution-phase catalysts $[39,228,229]$ and of various metal cathodes (mercury, platinum, stainless steel, carbon, and silver) [230-238].

Finally, another direction is to continue to explore electrochemical reduction of other halogenated environmental pollutants. In this review we have discussed electroreductions of selected chlorofluorocarbons, pesticides, flame retardants, and disinfection by-products. Some of these classes are too large to permit a discussion of all compounds that have been studied. On the other hand, some pollutants that fall into those classes have not been investigated, for instance tris(1,3-dichloro-2propyl)phosphate - an organophosphorus flame retardant used extensively in baby products. In addition, there are some historical pollutants not included in this review, including polychlorinated biphenyls, dioxins, the family of personal care products, chlorobenzoic acids, and chlorinated phenols, to name a few. Thus, there are many remaining substrates and concepts that could be examined for the remediation of environmental pollutants via electrochemistry.

\section{Abbreviations}

$\begin{array}{ll}\mathrm{CH}_{3} \mathrm{CN} & \text { acetonitrile } \\ \text { DBDE } & \text { decabromodiphenyl ether } \\ \text { DBP(s) } & \text { disinfection by-product(s) } \\ \text { DMF } & N, N \text {-dimethylformamide } \\ \text { DMSO } & \text { dimethyl sulfoxide }\end{array}$

HAAs haloacetic acids

HBCD hexabromocyclododecane

$\mathrm{TBABF}_{4} \quad$ tetra- $n$-butylammonium tetrafluoroborate 
TBABr tetra- $n$-butylammonium bromide

TBAI tetra- $n$-butylammonium iodide

TBAP tetra- $n$-butylammonium perchlorate

TBAPF $_{6} \quad$ tetra- $n$-butylammonium hexafluorophosphate

TEAP tetraethylammonium perchlorate

THMs trihalomethanes

$\mathrm{TMABF}_{4} \quad$ tetramethylammonium tetrafluoroborate

TMACl tetramethylammonium chloride

TMAP tetramethylammonium perchlorate

\section{References}

1. Rowland, F. S.; Molina, M. J. Nature 1974, 249, 810-812.

2. http://www.epa.gov/ozone/science/sc fact.html, accessed in July, 2012.

3. The Montreal Protocol on Substances that Deplete the Ozone Layer. UNEP, Ed. UNON: Nairobi, Kenya, 2000.

4. Rondinini, S.; Vertova, A., in: Electrochemistry of the Environment, Comninellis, C.; Chen, G., Eds., Springer, New York City, 2010, 279-293.

5. http://www.sciencedaily.com/releases/2009/06/090622171503. htm, accessed in November, 2013.

6. Montecatini Edison S.p.A., Italian patent 852,487 1969.

7. Smirnov, K. M.; Tomilov, A. P.; Feoktistov, L. G.; Gol'din, M. M. Zh. Prikl. Khim. 1978, 51, 701-704.

8. Wawzonek, S.; Willging, S. J. Electrochem. Soc. 1977, 124, 860861.

9. Tezuka, M.; Iwasaki, M. Denki Kagaku oyobi Kogyo Butsuri 1994, $62,1230-1232$.

10. Savall, A.; Dalbéra, S.; Abdelhedi, R; Bouguerra, M. L. J. Appl. Electrochem. 1990, 20, 1045-1052.

11. Savall, A.; Abdelhedi, R; Dalbéra, S.; Bouguerra, M. L. Electrochim. Acta 1990, 35, 1727-1737.

12. Cabot, P. L.; Centelles, M.; Segarra, L.; Casado, J. J. Electrochem. Soc. 2000, 147, 3734-3738.

13. Cabot, P. L.; Segarra, L.; Casado, J. Electrochem. Solid-State Lett. 2003, 6, B15-B18.

14. Cabot, P. L.; Segarra, L.; Casado, J. J. Electrochem. Soc. 2004, 151, B98-B104.

15. Cabot, P. L.; Centelles, M.; Segarra, L.; Casado, J. J. Electrochem. Soc. 1997, 144, 3749-3757.

16. Cabot, P. L.; Centelles, M.; Segarra, L.; Casado, J. J. Electroanal. Chem. 1997, 435, 255-258.

17. Kornienko, V. L.; Kolyagin, G. A.; Kornienko, G. V. Elektrokhimiya 1997, 33, 971-978.

18. Kolyagin, G. A.; Kornienko, G. V.; Vasil'eva, I. S. Elektrokhimiya 1996, 32, 302-304.

19. Inaba, M.; Sawai, K.; Ogumi, Z.; Takehara, Z. Chem. Lett. 1995, 24, 471-472.

20. Sonoyama, N.; Sakata, T. Environ. Sci. Technol. 1998, 32, 375378.

21. Sonoyama, N.; Fujii, H.; Sakata, T. J. Electrochem. Soc. 2002 , 149, D182-D186.

22. Sonoyama, N.; Ezaki, K.; Fujii, H.; Sakata, T. Electrochim. Acta 2002, 47, 3847-3851.

23. Sonoyama, N.; Sakata, T. Chem. Lett. 2002, 444-445.

24. Schizodimou, A.; Kyriacou, G.; Lambrou, C. J. Electroanal. Chem. 1999, 471, 26-31.

25. Georgolios, N.; Kyriacou, G.; Ritzoulis, G. J. Appl. Electrochem. 2001, 31, 207-212.

26. Delli, E.; Kouloumtzoglou, S.; Kyriacou, G.; Lambrou, C. Chem.
Commun. 1998, 1693-1694.

27. Fotiadis, T.; Kyriacou, G.; Lambrou C.; Hadjispyrou, S. J. Electroanal. Chem. 2000, 480, 249-254.

28. Titov, V.; Doherty, A. P.; Mishura, A.; Koshechko, V.; Pokhodenko, V. D. Theor. Exp. Chem. 2007, 43, 71-78.

29. Titov, V. E.; Mishura, A. M.; Koshechko, V. G. Theor. Exp. Chem. 2006, 42, 224-228.

30. Titov, V. E.; Mishura, A. M.; Koshechko, V. G. Visn. Hark. nac. univ. im. V. N. Karazina 2005, 12, 65-68.

31. Doherty, A. P.; Koshechko, V.; Titov, V.; Mishura, A. J. Electroanal. Chem. 2007, 602, 91-95.

32. Wagoner, E. R.; Peters, D. G. J. Electrochem. Soc. 2013, 160, G135-G141.

33. Wagoner, E. R.; Hayes, J. L.; Karty, J. A.; Peters, D. G. J. Electroanal. Chem. 2012, 676, 6-12.

34. Persinger, J. D.; Hayes, J. L.; Klein, L. J.; Peters, D. G.; Karty, J. A.; Reilly, J. P. J. Electroanal. Chem. 2004, 568, 157-165.

35. Bishop, G. W.; Karty, J. A.; Peters, D. G. J. Electrochem. Soc. 2007, 154, F65-F69.

36. Titov, V. E.; Lampeka, Y. D.; Gatsun, A. M.; Maloshtan, M.; Koshechko, V. G. Theor. Exp. Chem. 2001, 37, 168-173.

37. Titov, V. E.; Mishura, A. M.; Koshechko, V. G. Theor. Exp. Chem. 2011, 46, 399-408.

38. Koshechko, V.; Pokehodenko, V. D. Russ. Chem. Bull., Int. Ed. 2001, 50, 1929-1935.

39. Skljarevski, S.; Peverly, A. A.; Peters, D. G. J. Electroanal. Chem. 2011, 661, 39-43.

40. http://www.epa.gov/pesticides.htm, accessed in November, 2013.

41. Subbalakshmamma, M.; Reddy, S. J. Electroanalysis 1994, 6, 521526.

42. Madhavi, G.; Reddy, P. R. K.; Reddy, S. J. J. Electrochem. Soc. India 1995, 44, 185-189.

43. Wothing, C. R.; Walker, S. B., Eds., The Pesticide Manual (A World Compendium), $8^{\text {th }}$ edition, The British Crop Protection Council, 1987, Croydon, England.

44. Pospišsil, L; Sokolová, R.; Colombini, M. P.; Giannarelli, S.; Fuoco, R. J. Electroanal. Chem. 1999, 472, 33-41.

45. Will, W. Fresenius J. Anal. Chem. 1995, 353, 215-218.

46. Pospišil, L; Sokolová, R.; Colombini, M. P.; Giannarelli, S.; Fuoco, R. Microchem. J. 2000, 67, 305-312.

47. Hromadová, M.; Pospíšil, L.; Zálišs, S.; Fanelli, N. J. Inclusion Phenom. Macrocyclic Chem. 2002, 44, 373-380.

48. Sreedhar, N. Y.; Samatha, K.; Sujatha, D.; Ravindranath Babu, T. Indian J. Environ. Prot. 2001, 21, 806-810.

49. Sreedhar, N. Y.; Swarupa, C. H.; Siv Aprasad, M.; Seenu Naik, M.; Dhananjayulu, M. Chem. Sci. Trans. 2013, 2, 997-1003.

50. Sreedhar, N. Y.; Babu, T. R.; Samatha, K.; Sujatha, D.; Thriveni, T. J. AOAC Int. 2002, 85, 731-735.

51. Fukami, H.; Nakajima, M. Botyu-Kagaku 1953, 18, 6-9.

52. Rosenthal, I.; Lacoste, R. J. J. Am. Chem. Soc. 1959, 81, 32683270.

53. Reddy, A. S.; Reddy, S. J. Indian J. Chem. 1984, 23A, 619-620.

54. Tandon, R.; Bala, I; Singh, M. Z. Phys. Chem. (Leipzig) 1986, 267, 340-348.

55. Merica, S. G.; Jędral, W.; Lait, S.; Keech, P.; Bunce, N. J. Can. J. Chem. 1999, 77, 1281-1288.

56. Schweizer, S.; Rusling, J. F.; Huang, Q. Chemosphere 1994, 28, 961-969.

57. Jabbar, M. A.; Shimakoshi, H.; Hisaeda, Y. Chem. Commun. 2007, 1653-1655.

58. Mubarak, M. S.; Gach, P. C.; Peters, D. G. Electroanalysis 2006, $18,417-422$.

59. Gach, P. C.; Mubarak, M. S.; Karty, J. A.; Peters, D. G. J. Electrochem. Soc. 2006, 154, F1-F7.

60. Wagoner, E. R.; Karty, J. A.; Peters, D. G. J. Electroanal. Chem. 2013, 706, 55-63.

61. den Besten. C.; Vet, J. J.; Besselink, H. T.; Kiel, G. S.; van Berkel, 
B. J.; Beems, R.; van Bladeren, P. J. Toxicol. Appl. Pharmacol. 1991, 111, 69-81.

62. Mubarak, M. S.; Peters, D. G. J. Electroanal. Chem. 1997, 435, 47-53.

63. Chaussard, J.; Folest, J.; Nédélec, J.; Périchon, J.; Sibille, S.; Troupel, M. Synthesis 1990, 369-381.

64. Golinske, D.; Voss, J.; Adiwidjaja, G. Collect. Czech. Chem. Commun. 2000, 65, 862-880.

65. Miyoshi, K.; Kamegaya, Y.; Matsumura, M. Chemosphere 2004, 56, 187-193.

66. Miyoshi, K.; Kamegaya, Y.; Matsumura, M. Electrochemistry 2004, 72, 830-832.

67. Miyoshi, K.; Alfafara, C. G.; Matsumura, M. J. Electroanal. Chem. 2004, 568, 293-300.

68. Guena, T.; Wang, L.; Gattrell, M.; MacDougall, B. J. Electrochem. Soc. 2000, 147, 248-255.

69. The Dow Chemical Company, US patent 3,677,916 1972.

70. Kulikov, S. M.; Plekhanov, V. P.; Tsyganok, A. I.; Schlimm, C.; Heitz, E. Electrochim. Acta 1996, 41, 527-531.

71. Plekhanov, V. P; Tsyganok, A. I.; Kulikov, S. M. Russ. Chem. Bull. 1995, 44, 1091-1095.

72. Lee, J. J.; Yao, C. P.; Yung, Y. W.; Wan, C. C. Environ. Sci. Technol. 1992, 26, 553-556.

73. Sugimoto, H.; Matsumoto, S.; Sawyer, D. T. Environ. Sci. Technol. 1988, 22, 1182-1186.

74. Gach, P. C.; Karty, J. A.; Peters, D. G. J. Electroanal. Chem. 2008, 612, 22-28.

75. Páramo-Garcío, U.; Ávila-Rodríguez, M.; García-Jiménez, M. G.; Gutiérrez-Granados, S.; Ibáñez-Cornejo, J. G. Electroanalysis 2006, 18, 904-910.

76. Páramo-Garcío, U.; Gutiérrez-Granados, S.; García-Jiménez, M. G.; Ibáñez-Cornejo, J. G. J. New Mater. Electrochem. Syst. 2010, 13, 356-360.

77. Simagina, V. I.; Stoyanova, L; Yakovlev, V.; Nosov, A.; Krukova, G. N.; Likholobov, V. Organohalogen Compd. 1998, 36, 313-316.

78. Simagina, V. I.; Likholobov, V.; Bergeret, G.; Gimenez, M. T.; Renouprez, A. Appl. Catal., B 2003, 40, 293-304.

79. Yakoviev, V. A.; Simagina, V. I.; Trukhan, S. N.; Likholobov, V. A. Kinet. Catal. 2000, 41, 25-32.

80. Simagina, V. I.; Renouprez, A. J.; Bergeret, G.; Gimenez, M. T.; Stoyanova, I. V.; Egorova, M. B.; Likholobov, V. A. Organohalogen Compd. 1999, 40, 563-566.

81. Bunce, N. J.; Merica, S. G.; Jędral, W.; Banceu, C.; Lipkowski, J. Int. Conf. Rem. Chlorinated Recalcitrant Compd. 1998, 1, 449454.

82. Merica, S .G.; Bunce, N. J.; Jędral, W.; Lipkowski, J. J. Appl. Electrochem. 1998, 28, 645-651.

83. Merica, S. G.; Banceu, C. E.; Jędral, W.; Lipkowski, J.; Bunce, N. J. Environ. Sci. Technol. 1998, 32, 1509-1514.

84. Wang, Y.; Lu, X.; Lin, L.; Li, T. Huanjing Kexue Yu Jishu 2010, $33,21-24$.

85. Wang, Y.; Lu, X.; Lin, L. Huanjing Kexue Yu Jishu 2011, 34, 92-94.

86. Matsunaga, A.; Yasuhara, A. Chemosphere 2005, 59, 14871496.

87. Farwell, S. O.; Beland, F. A.; Geer, R. D. J. Electroanal. Chem. 1975, 61, 303-313.

88. Beland, F. A.; Farwell, S. O.; Callis, P. R.; Geer, R. D. J. Electroanal. Chem. 1977, 78, 145-159.

89. Dolfing, J.; Harrison, B. K. Environ. Sci. Technol. 1992, 26, $2213-$ 2218.

90. Dolfing, J.; Harrison, B. K. FEMS Microbiol. Ecol. 1993, 13, 23-30.

91. Beland, F. A.; Farwell, S. O.; Robocker, A. E.; Geer, R. D. J. Agric. Food Chem. 1976, 24, 753-756.

92. Beland, F. A.; Farwell, S. O.; Callis, P. R.; Geer, R. D. J. Electro- anal. Chem. 1977, 78, 145-159.

93. Fukami, H.; Kimura, H.; Nakazima, M. Botyu-Kagaku 1953, 18, 51-57.

94. Tandon, R.; Singh, N.; Singh, M. J. Indian Chem. Soc. 1989, 66, 479-481.

95. Bachmann, T.; Vermes, I.; Heitz, E. Elektrochem. Energ. Umwelttech. 1991, 124, 221.

96. Kulikov, S. M.; Plekhanov, V. P.; Tsyganok, A. I.; Schlimm, C.; Heitz, E. Electrochim. Acta 1996, 41, 527-531.

97. Böck, R. Galvanotechnik 2003, 94, 2414-2421.

98. Matsunaga, A.; Yasuhara, A. Chemosphere 2005, 59, 14871496.

99. Prathap, M. U.; Srivastava, R. Electrochim. Acta 2013, 108, 145152.

100. Kumaravel, A; Vincent, S.; Chandrasekaran, M. Anal. Methods 2013, 5, 931-938.

101. Merz, J. P.; Gamoke, B. C.; Foley, M. P.; Raghavachari, K.; Peters, D. G. J. Electroanal. Chem. 2011, 660, 121-126.

102. Peverly, A. A.; Karty, J. A.; Peters, D. G. J. Electroanal. Chem. 2013, 692, 66-71.

103. http://www.epa.gov/oppsrrd1/REDs/factsheets/triclosan_fs.htm, accessed in January, 2013.

104. Pemberton, R. M.; Hart, J. P. Anal. Chim. Acta 1999, 390, 107-115.

105. Safavi, A.; Maleki, N. Shahbaazi, H. R. Anal. Chim. Acta 2003, 494, 225-233.

106. Safavi, A.; Maleki, N., Shahbaazi, H. R. Bull. Electrochem. 2005, 21, 229-232.

107. Wang, L.; Chu, S.; Chin, C. Bull. Electrochem. 2004, 20, $225-$ 229.

108. Wang, L.; Chu, S. Chromatographia 2004, 60, 385-390.

109. Knust, K. N.; Foley, M. P.; Mubarak, M. S.; Skljarevski, S.; Raghavachari, K.; Peters, D. G. J. Electroanal. Chem. 2010, 638, 100-108.

110. Pospíšil, L.; Trsková, R.; Fuoco, R.; Colombini, M. P. J. Electroanal. Chem. 1995, 395, 189-193.

111. Higuera, M. J.; Ruiz Montoya, M.; Marín Galvín, R.; Rodríguez Mellado, J. M. J. Electroanal. Chem. 1999, 474, 174-181.

112. Zuman, P.; Privman, M.; Shibata, M.; Ludvik, J. Turkish J. Chem. 2000, 24, 311-331.

113. Caetano, J.; Homem-de-Mello, P.; da Silva, A. B. F.; Ferreira, A. G.; Avaca, L. A. J. Electroanal. Chem. 2007, 608, 47-51.

114. Guse, D.; Bruzek, M. J.; DeVos, P.; Brown, J. H. J. Electroanal. Chem. 2009, 626, 171-173.

115. Bruzek, M. J.; Henderson, J. K.; Hull, R. L.; Becht, S. B.; Brown, J. H. J. Electroanal Chem. 2010, 642, 13-16.

116. De Souza, D.; de Toledo, R. A.; Galli, A.; Salazar-Banda, G. R.; Silva, M. R. C.; Garbellini, G. S.; Mazo, L. H.; Avaca, L. A.; Machado, S. A. S. Anal. Bioanal. Chem. 2007, 387, 22452253.

117. Figueiredo-Filho, L. C. S.; Azzi, D. C.; Janegitz, B. C.; FatibelloFilho, O. Electroanalysis 2012, 24, 303-308.

118. Švorc, L'; Rievaj, M.; Bustin, D. Sens. Actuators, B 2013, 181, 294-300.

119. Bartak, D. E.; Houser, K. J.; Rudy, B. C.; Hawley, M. D. J. Am. Chem. Soc. 1972, 94, 7526-7530.

120. Sokolová, R.; Hromadová, M.; Fiedler, J.; Pospíšil, L.; Giannarelli, S.; Valášek, M. J. Electroanal. Chem. 2008, 622, 211-218.

121. Soderlund, D. M.; Clark, J. M.; Sheets, L. P.; Mullin, L. S.; Piccirillo, V. J.; Sargent, D.; Stevens, J. T.; Weiner, M. L. Toxicology 2002, 171, 3-59.

122. Jehring, H.; de la Chevallerie-Haaf, U.; Meyer, A.; Henze, G. Fresenius Z Anal. Chem. 1989, 332, 890-897.

123. Coomber, D. C.; Tucker, D. J.; Bond, A. M. J. Electroanal. Chem. 1997, 430, 215-225.

124. Coomber, D. C.; Tucker, D. J.; Bond, A. M. Anal. Chem. 1996, 
$68,1267-1271$.

125. Coomber, D. C.; Tucker, D. J.; Bond, A. M. J. Electroanal. Chem. 1997, 426, 63-73.

126. Coomber, D. C.; Tucker, D. J.; Bond, A. M. J. Electroanal. Chem. 1998, 452, 5-11.

127. Sreedhar, M.; Reddy, M. T.; Balaji, K.; Reddy, J. S. Int. J. Environ. Anal. Chem. 2006, 86, 757-765.

128. Sreedhar, M.; Reddy, J. S. Fresenius Environ. Bull. 2002, 11, 371-376.

129. Oudou, H. C.; Alonso, R. M.; Bruun Hansen, H. C. Anal. Chim. Acta 2004, 523, 69-74.

130. Oudou, H. C.; Alonso, R. M.; Jiménez, R. M. Electroanalysis 2001, 13, 72-77.

131. Naidu, N. V. S.; Hemasundaram, A.; Padmaja, K.; Saraswathi, K. Trans. SAEST 2005, 40, 103-105.

132. Covaci, A.; Harrad, S.; Abdallah, M. A.; Ali, N.; Law, R. J.; Herzke, D.; de Wit, C. A. Environ. Int. 2011, 37, 532-556.

133. Han, W.; Wang, S.; Huang, H.; Luo, L.; Zhang, S. J. Environ. Sci. (Beijing, China) 2013, 25, 2306-2312.

134. Law, R. J.; Allchin, C. R.; de Boer, J.; Covaci, A.; Herzke, D.; Lepom, P.; Morris, S.; Tronczynki, J.; de Wit, C. A. Chemosphere 2006, 64, 187-208.

135. Lou, S.; Yang, S.; Sun, C.; Wang, X. Water Res. 2011, 45, 1519-1528.

136. Renner, R. Environ. Sci. Technol. 2004, 38, 14A-15A.

137. http://chm.pops.int/Programmes/NewPOPs/The9newPOPs/tabid/672/Language/en-us/default.aspx, accessed in January, 2014.

138. Rondinini, S.; Mussini, P. R.; Specchia, M.; Vertova, A. J. Electrochem. Soc. 2001, 148, D102-D107.

139. Fiori, G.; Mussini, P. R.; Rondinini, S.; Vertova, A. Ann. Chim. (Rome, Italy) 2002, 92, 963-972.

140. Xu, Y.; Zhu, Y.; Zhao, F.; Ma, C. Appl. Catal., A 2007, 324, $83-86$.

141. Zhu, Y.; Xu, Y.; Ma, H.; Zhao, F.; Ma, C. Wuli Huaxue Xuebao 2009, 25, 1190-1194.

142. http://www.epa.gov/fedfac/pdf/technical_fact_sheet_pbde_pbb. pdf, accessed in January, 2014.

143. Rusling, J. F.; Miaw, C. L. Environ. Sci. Technol. 1989, 23, 476-479.

144. Huang, Q.; Rusling, J. F. Environ. Sci. Technol. 1995, 29, 98103.

145. Bonin, P. M. L.; Edwards, P.; Bejan, D.; Lo, C. C.; Bunce, N. J.; Konstantinov, A. D. Chemosphere 2005, 58, 961-967.

146. Konstantinov, A.; Bejan, D.; Bunce, N. J.; Chittim, B.; McCrindle, R.; Potter, D.; Tashiro, C. Chemosphere 2008, 72, $1159-1162$.

147. Peverly, A. A.; Pasciak, E. M.; Strawsine, L. M.; Wagoner, E. R.; Peters, D. G. J. Electroanal. Chem. 2013, 704, 227-232.

148. http://chm.pops.int/Convention/POPsReviewCommittee/Chemicals/tabid/243/Default.aspx, accessed in November, 2013.

149. Wagoner, E. R.; Baumberger, C. P.; Peverly, A. A.; Peters, D. G. J. Electroanal. Chem. 2014, 713, 136-142.

150. Baron, L.; Kozłowska, A.; Kurek, S. Chemik 2011, 65, 10031010.

151. Baron, L.; Kozłowska, A.; Kurek, S. Czasopismo Tech. Chem. 2011, 10, 31-38.

152. Romańczyk, P. P.; Noga, K.; Radoń, M.; Rotko, G.; Kurek, S. Electrochim. Acta 2013, 110, 619-627.

153. Luca, C.; Giomini, C.; Rampazzo, L. J. Electroanal. Chem. 1987, 238, 215-223

154. Troll, T.; Ollman, G. W. Tetrahedron Lett. 1981, 22, 34973500 .

155. Goulart, M. O. F.; Lisboa, M. B. S.; Cavalcanti, C. M.; Tonholo, J.; Navarro, M.; Soares, N. A.; Longo, R. L. J. Electroanal. Chem. 2004, 567, 67-75.

156. Belbruno. J. J. International patent WO 2013/033541 A1 2013.

157. Chen, H-J.; Zhang, Z-H.; Cai, R.; Kong, X-Q.; Chen, X.; Liu,
Y-N.; Yao, S-Z. Analyst 2013, 138, 2769-2776.

158. Lin, M.; Liu, Y.; Chen, X.; Fei, S.; Fang, Y.; Liu, C.; Cai, Q. Biosens. Bioelectron. 2013, 45, 82-88.

159. Ghernaout, D.; Ghernaout, B. Desalin. Water Treat. 2010, 16, $156-175$.

160. Richardson, S. D.; Postigo, C., in: The Handbook of Environmental Chemistry, Barceló, D., Ed., SpringLink, 2012, 20, 93-138.

161. Ivahnenko, T.; Zogorski, J. S. Sources and Occurrence of Chloroform and other Trihalomethanes in Drinking-water Supply Wells in the United States; U.S. Department of the Interior, U.S. Geological Survey: 1986-2001.

162. http://water.epa.gov/drink/contaminants/basicinformation/disinfectionbyproducts.cfm\#content, accessed in July, 2010.

163. Wright, J. M.; Schwartz, J.; Dockery, D. W. Environ. Health Perspect. 2004, 112, 920-925.

164. Pourmoghaddas, H.; Stevens, A. A. Water Research 1995, 29, 2059-2062.

165. Horth, H. Aqua 1989, 38, 80-100.

166. Arbab-Zavar, M. H.; Rounaghi, G. H.; Chamsaz, M.; Ashraf, N. Asian J. Chem. 2009, 21, 2241-2252.

167. Yoo, K. S.; Park, S. Y.; Yang, S. B.; Woo, S. B. Anal. Sci. Technol. 1997, 10, 264-273.

168. Sonoyama, N.; Hara, K.; Sakata, K. Chem. Lett. 1997, 26, 131132.

169. Hori, Y.; Murata, K.; Oku, T. Chem. Lett. 2003, 32, 230-231.

170. Isse, A. A.; Sandonà, G.; Durante, C.; Gennaro, A. Electrochim. Acta 2009, 54, 3235-3243.

171. Isse, A. A.; Berzi, G.; Falciola, L.; Rossi, M.; Mussini, P. R.; Gennaro, A. J. Appl. Electrochem. 2009, 39, 2217-2225.

172. Rondinini, S.; Vertova, A. Electrochim. Acta 2004, 49, 40354046.

173. Durante, C.; Isse, A. A.; Sandonà, G.; Gennaro, A. Appl. Catal., B 2009, 88, 479-489.

174. Peverly, A. A.; Peters, D. G. Anal. Chem. 2012, 84, 6110 6115.

175. Fiori, G.; Rondinini, S.; Sello, G.; Vertova, A.; Cirja, M.; Conti, L. J. Appl. Electrochem. 2005, 35, 363-368.

176. Radjenović, J.; Farré, M. J.; Mu, Y.; Gernjak, W.; Keller, J. Water Research 2012, 46, 1705-1714.

177. Sonoyama, N.; Sakata, T. Environ. Sci. Technol. 1999, 33, 3438-3442.

178. Sonoyama, N.; Ezaki, K.; Sakata, T. Adv. Environ. Res. 2001, $6,1-8$.

179. Sonoyama, N.; Seike, S.; Sueoka, T.; Sakata, T. J. Appl. Electrochem. 2003, 33, 1049-1055.

180. Elving, P. J.; Rosenthal, I.; Kramer, M. K. J. Am. Chem. Soc. 1951, 73, 1717-1722.

181. Elving, P. J.; Tang, C. J. Am. Chem. Soc. 1950, 72, 32443246.

182. Korshin, G. V.; Jensen, M. D. Electrochim. Acta 2001, 47, 747-751.

183. Ordaz, A. A.; Rocha, J. M.; Aguilar, F. J. A.; Granados, S. G.; Bedioui, F. Analusis 2000, 28, 238-244.

184. Carvalho, E. R.; Filho, N. C.; Firmino, A.; Oliveira, O. N., Jr.; Mattoso, L. H. C.; Martin-Neto, L. Sens. Lett. 2006, 4, 129134.

185. Dobson D. J.; Saini, S. Anal. Chem. 1997, 69, 3532-3538.

186. Wiyaratn, W.; Hrapovic, S.; Liu, Y.; Surareungchai, W.; Luong, J. H. T. Anal. Chem. 2005, 77, 5742-5749.

187. Wiyaratn, W.; Somasundrum, M.; Surareungchai, W. Anal. Chem. 2004, 76, 859-862.

188. Wiyaratn, W.; Somasundrum, M.; Surareungchai, W. Analyst 2005, 130, 626-631.

189. Altamar, L.; Fernández, L.; Borras, C.; Mostany, J.; Carrero, H.; Scharifker, B. Sens. Actuators, B 2010, 146, 103-110.

190. Suedee, R.; Intakong, W.; Lieberzeit, P. A.; Wanichapichart, P.; Chooto, P.; Dickert, F. L. J. App. Polym. Sci. 2007, 106, 
3861-3871.

191. Akhtar, P.; Too, C. O.; Wallace, G. G. Anal. Chim. Acta 1997, $341,141-153$.

192. Wei, M.; Li, M.; Li, N.; Gu, Z.; Zhou, X. Talanta 2001, 53, $1045-1052$.

193. Liu, B.; Hu, X.; Deng, Y.; Yang, S.; Sun, C. Electrochem. Commun. 2010, 12, 1395-1397.

194. Bellomunno, C.; Bonanomi, D.; Falciola, L.; Longhi, M.; Mussini, P. R.; Doubova, L. M.; Di Silvestro, G. Electrochim. Acta 2005, 50, 2331-2341.

195. Isse, A. A.; Gottardello, S.; Durante, C.; Gennaro, A. Phys. Chem. Chem. Phys. 2008, 10, 2409-2416.

196. Durante, C.; Huang, B.; Isse, A. A.; Gennaro, A. Appl. Catal., B 2012, 126, 355-362.

197. Simonet, J. Electrochem. Commun. 2005, 7, 74-80.

198. Simonet, J. Electrochem. Commun. 2010, 12, 1475-1478.

199. Simonet, J.; Poizot, P.; Laffont, L. J. Electroanal. Chem. 2006, 591, 19-26.

200. Simonet, J. Electrochem. Commun. 2010, 12, 250-253.

201. Ardizzone, S.; Cappelletti, G.; Doubova, L.; Mussini, P. R.; Passeri, S. M.; Rondinini, S. Electrochim. Acta 2003, 48, 37893796.

202. Hoshi, N.; Nozu, D. Electrochemistry 2006, 74, 593-595.

203. Minguizzi, A.; Lugaresi, O.; Aricci, G.; Rondinini, S.; Vertova, A. Electrochem. Commun. 2012, 22, 25-28

204. Walsh, F.; Mills, G. Chem. Ind.-London 1993, 15, 576-580.

205. Scott, K. Dev. Chem. Eng. Miner. Process. 1992, 1, 71-117.

206. Popovtzer, R.; Shacham-Diamand, Y.; Rishpon, J., in: Handbook of Biosensors and Biochips, Marks, R. S.; Lowe, C. R.; Cullen, D. C.; Lowe, C. R.; Weetall, H. H., Eds., Wiley, New York, 2007, 939-947.

207. He, J.; Ela, W. P.; Betterton, E. A.; Arnold, R. G.; Sáez, A. E. Ind. Eng. Chem. Res. 2004, 43, 7965-7974.

208. Lunte, S. M.; Lunte, C. E.; Kissinger, P. T., in: Laboratory Techniques in Electroanalytical Chemistry; Kissinger, P. T.; Heineman, W. R., Eds., Marcel Dekker, New York, 1996, 813-853.

209. Noyhouzer, T.; Mandler, D. Electroanalysis 2013, 25, 109115 .

210. Chen, C.; Zhang, J.; Du, Y.; Yang, X.; Wang, E. Analyst 2009, 135, 1010-1014

211. Richter, P.; Toral, M. I.; Abbott, B. Electroanalysis 2002, 14, 1288-1293.

212. Naseri, N. G.; Baldock, S. J.; Economou, A.; Goddard, N. J.; Fielden, P. R. Anal. Bioanal. Chem. 2008, 391, 1283-1292.

213. Cacho, F.; Jankuv, L.; Lauko, L.; Kroliak, M.; Manova, A.; Beinrohr, E. Talanta 2013, 116, 195-198.

214. Wagner, M.; Kvarnström, C.; Ivaka, A. in: Electrochemical Nanofabrication: Principles and Applications, Wei, D., Ed., Pan Stanford Publishing Pte. Ltd., Singapore, 2012, 17-144.

215. Feroci, M.; Orsini, M.; Rossi, L.; Inesi, A. Curr. Org. Synth.
2012, 9, 40-52.

216. Ma, J.; Hong, X. J. Environ. Manage. 2012, 99, 104-109.

217. Fuchigami, T.; Inagi, S., in: Electrochemical Aspects of Ionic Liquids, 2nd edition, Hiroyuki, O., Ed., Wiley, 2011, 101-128.

218. Jutz, F.; Andanson, J-M.; Baiker, A. Chem. Rev. 2011, 111, 322-353.

219. Bhat, M. A.; Ingole, P. P.; Chaudhari, V. R.; Haram, S. K. J. Phys. Chem. B 2009, 113, 2848-2853.

220. Sweeny, B. K.; Peters, D. G. Electrochem. Commun. 2001, 3, $712-715$

221. Shen, Y.; Tajima, M. A.; Fuchigami, T. Electrochemistry 2004, 72, 849-851.

222. Zhang L.; Niu, D. F.; Zhang, K.; Zhang, G. R.; Luo, Y. W.; Lu, J. X. Green Chem. 2008, 10, 202-206.

223. Niu, D.; Zhang, J.; Zhang, K.; Xue, T.; Lu, J.; Chin. J. Chem. 2009, 27, 1041-1044.

224. Hiejima, Y.; Hayashi, M.; Uda, A.; Oya, S.; Kondo, H.; Senboku, H.; Takahashi, K. Phys. Chem. Chem. Phys. 2010, 12, 1953-1957.

225. Weinberg, N. L.; Hoffmann, A. K.; Reddy, T. B. Tetrahedron Lett. 1971, 12, 2271-2274.

226. Sánchez-Sánchez, C. M.; Montiel, V.; Tryk, D. A.; Aldaz, A.; Fujishima, A. Pure Appl. Chem. 2001, 73, 1917-1927.

227. Sánchez-Sánchez, C. M.; Expósito, E.; Batanero, B.; Montiel, V.; Barba, F.; Aldaz, A., in: Trends in Electrochemistry and Corrosion at the Beginning of the 21st Century, Brillas, E.; Cabot, P-L., Eds., Publicacions de la Universitat de Barcelona, 2004, 431-442.

228. Fauvarque, J. F.; Jutand, A.; Francois, M. J. Appl. Electrochem. 1988, 18, 109-115.

229. Folest, J-C.; Duprilot, J-M.; Périchon, J.; Robin, Y.; Devynck, J. Tetrahedron Lett. 1985, 26, 2633-2636.

230. Murcia, N. S.; Peters, D. G. J. Electroanal. Chem. 1992, 326, 69-79.

231. Heintz, M.; Sock, O.; Saboureau, C.; Périchon, J.; Troupel, M. Tetrahedron 1988, 44, 1631-1636.

232. Sock, O.; Troupel, M.; Périchon, J. Tetrahedron Lett. 1985, 26, 1509-1512.

233. Koshechko, V. G.; Titov, V. E.; Lopushanskaya, V. A. Electrochem. Commun. 2002, 4, 655-658.

234. Isse, A. A.; Gennaro, A. J. Electrochem. Soc. 2002, 149, D113D117.

235. Scialdone, O.; Galia, A.; Errante, G.; Isse, A. A.; Gennaro, A.; Filardo, G. Electrochim. Acta 2008, 53, 2514-2528.

236. Isse, A. A.; Ferlin, M. G.; Gennaro, A. J. Electroanal. Chem. 2005, 581, 38-45.

237. Zhang, J.; Niu, D.; Lan, Y.; Wang, H.; Zhang, G.; Lu, J. Synth. Commun. 2011, 41, 3720-3727.

238. Gennaro, A.; Sánchez-Sánchez, C. M.; Isse, A. A.; Montiel, V. Electrochem. Commun. 2004, 6, 627-631. 